\title{
Type II SOCS as a feedback repressor for GH-induced Igf1 expression in carp hepatocytes
}

\author{
Xue Jiang, Jia Xiao, Mulan He, Ani Ma and Anderson O L Wong
}

School of Biological Sciences, University of Hong Kong, Pokfulam, Hong Kong

Correspondence should be addressed

to A O L Wong

Email

olwong@hku.hk

\begin{abstract}
Type II suppressor of cytokine signaling (SOCS) serve as feedback repressors for cytokines and are known to inhibit growth hormone (GH) actions. However, direct evidence for SOCS modulation of GH-induced insulin-like growth factor 1 (Igf1) expression is lacking, and the post-receptor signaling for SOCS expression at the hepatic level is still unclear. To shed light on the comparative aspects of SOCS in GH functions, grass carp was used as a model to study the role of type II SOCS in GH-induced Igf1 expression. Structural identity of type II SOCS, Socs1-3 and cytokine-inducible SH2-containing protein (Cish), was established in grass carp by $5^{\prime} / 3^{\prime}-\mathrm{RACE}$, and their expression at both transcript and protein levels were confirmed in the liver by RT-PCR and LC/MS/MS respectively. In carp hepatocytes, GH treatment induced rapid phosphorylation of JAK $_{2}$, STATs, MAPK, PI3K, and protein kinase B (Akt) with parallel rises in socs1-3 and cish mRNA levels, and these stimulatory effects on type II SOCS were shown to occur before the gradual loss of igf1 gene expression caused by prolonged exposure of $\mathrm{GH}$. Furthermore, $\mathrm{GH}$-induced type II

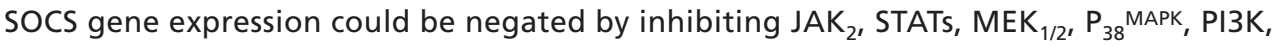
and/or Akt respectively. In $\mathrm{CHO}$ cells transfected with carp GH receptor, over-expression of these newly cloned type II SOCS not only suppressed JAK ${ }_{2} / \mathrm{STAT}_{5}$ signaling with GH treatment but also inhibited GH-induced grass carp Igf1 promoter activity. These results, taken together, suggest that type II SOCS could be induced by GH in the carp liver via JAK 2 /STATs, MAPK, and PI3K/Akt cascades and serve as feedback repressors for GH signaling and induction of igf1 gene expression.
\end{abstract}

\section{Key Words}

- suppressor of cytokine signaling

- growth hormone

- insulin-like growth factor

- intracellular feedback

- signal transduction

- hepatocytes

- grass carp

\section{Introduction}

The members of suppressor of cytokine signaling (SOCS) are key regulators of innate (Strebovsky et al. 2012) and adaptive immune systems (Tamiya et al. 2011). In mammals, at least eight members of SOCS family, including Socs1-7 and cytokine-inducible SH2-containing protein (Cish), have been identified (Jin et al. 2008). All of them share the common features with a SH2 domain in the central core followed by a highly conserved SOCS box in the C-terminus. Socs1 and Socs3 also have the additional kinase inhibitory region (KIR) and extended $\mathrm{SH} 2$ motif (ESS) upstream of SH2 domain, which are absent in other SOCS members (Piessevaux et al. 2008b). SOCS proteins are widely expressed at tissue level (Delgado-Ortega et al. 2011), and their production can be induced by microbial/ viral infection or by cytokine treatment (Hebenstreit

Published by Bioscientifica Ltd. 
et al. 2003, Cheng et al. 2009). At cellular level, SOCS expression is well documented to serve as the feedback repressor for cytokine signaling via inhibition of JAK/ STAT pathway (Croker et al. 2008) and plays a protective role in preventing hyperactivation of immune system, which can lead to autoimmune/inflammatory disorders (Liang et al. 2014). In mammals, SOCS proteins can also act as negative modulators for growth hormone (GH) actions (Birzniece et al. 2009) and contribute to the cross talk between immune system and somatotropic axis (Ahmed \& Farquharson 2010). In rodents, GH treatment is known to induce Socs2, Socs3, and Cish expression in the liver, both in vivo and in vitro (Adams et al. 1998, TolletEgnell et al. 1999). Given that (i) $\mathrm{JAK}_{2} / \mathrm{STAT}_{5}$ pathway is a key component of GH signaling (Vijayakumar et al. 2010); (ii) Socs $1-3$ and Cish expression can inhibit $\mathrm{JAK}_{2}$ activity, STAT $_{5}$ phosphorylation, and GH-responsive promoters (Greenhalgh \& Alexander 2004, Greenhalgh et al. 2005); and (iii) Socs2 knockout can lead to gigantism in mouse model (Metcalf et al. 2000) and the growth enhancement is dependent on $\mathrm{STAT}_{5}$ (Greenhalgh et al. 2002a), SOCS proteins, especially Socs2, are proposed to be the feedback repressors for GH signaling, which may contribute to the pulsatile actions of GH on Igf1 production at the hepatic level (Choi \& Waxman 2000).

Of note, conflicting results against the role of SOCS as a 'signal terminator' for GH actions have also been reported. In mice, SOCS2 over-expression could induce gigantism with accelerated growth as in the case of Socs2 knockout (Greenhalgh et al. 2002b). Besides, serum levels and hepatic content of Igf1 in Socs2-null mice were found to be similar to those of wild-type littermates (Metcalf et al. 2000). In the same study, the role of SOCS2 in GH-induced IGF1 production and body growth was also questioned, as most of the organs in Socs2-null mice were enlarged without parallel rise in IGF1 expression. In transfection studies with cell lines (e.g., HEK293 cells), SOCS2 over-expression could induce dual effects on GH signaling, being inhibitory at low doses but stimulatory at high doses (Favre et al. 1999). In 3T3-F442A adipocytes, however, SOCS2 and CISH expressions had no effects on GH-induced promoter activity in GH-responsive genes (e.g., Spi-2.1) (Adams et al. 1998). Although the mechanisms for SOCS inhibition of JAK/STAT pathway through KIR inhibition of Janus kinase (JAK) activity, blocking signal transducer and activator of transcription (STAT) recruitment by SH2 domain, and decaying activated receptor complex via SOCS box have been documented (Greenhalgh \& Alexander 2004, Greenhalgh et al. 2005), except for a single report in $\mathrm{C} 2 \mathrm{C} 12$ myoblasts, suggesting that mitogen-activated protein kinases (MAPK) and phosphoinositide 3-kinase (PI3K) activation may inhibit GH-induced SOCS2 and CISH expression (Sadowski et al. 2001), not much is known for the post-receptor signaling for GH-induced SOCS expression, especially in the liver with relevance to IGF1 production. To date, the direct evidence for SOCS modulation of IGF1 expression induced by GH is still lacking.

In recent years, SOCS proteins have been cloned in fish models, e.g., trout (Wang et al. 2010, Maehr et al. 2014), salmon (Skjesol et al. 2014), catfish (Yao et al. 2015), turbot (Zhang et al. 2011), and zebrafish (Wang et al. 2011). Data mining of genome databases not only reveals the orthologues of mammalian SOCS but also reveals new paralogues of Cish, Socs3, and Socs5 unique to fish species (Jin et al. 2008, Wang et al. 2011), which are presumably the result of fish-specific 3R genome duplication (Kassahn et al. 2009). Based on the phylogenetic analysis of the new sequences with those reported in invertebrates, two families of SOCS, type I and type II SOCS, have been proposed (Jin et al. 2008). Type I SOCS (including Socs4-7, Socs5b, and Socs9 found in both vertebrates and invertebrates) represents the lineage closely related to the ancestral SOCS, whereas type II SOCS (including Socs1-5, Cish, and the CISH homologue Socs9) can be identified only in vertebrates and believed to be derived from type I SOCS by gene duplication (Jin et al. 2007, 2008). Functional studies in fish models also reveal that type II SOCS (e.g., Socs1-3 and Cish) are highly responsive to microbial infection or exposure to endotoxin/cytokines, whereas the corresponding responses for type I SOCS are marginal/undetectable (Wang et al. 2010, 2011). For the role of SOCS in GH signaling, notable rises of socs 1 and $s \cos 3$ mRNA could be found in the liver of zebrafish with GH transgene. However, Igf1 expression was reduced with no effects on body growth or $\mathrm{JAK}_{2} /$ $\mathrm{STAT}_{5}$ signaling components (Studzinski et al. 2009). Recently, elevations of socs 1 and socs 2 transcripts have also been reported in trout liver during cortisol inhibition of GH-induced Igf1 expression (Philip et al. 2015), suggesting that SOCS proteins may play a role in Igf1 regulation by GH in fish model.

To shed light on the role of SOCS in GH functions in fish model, type II SOCS, including Socs1-3 and Cish, were cloned in grass carp and their gene copy number and tissue expression, especially in the liver, were determined. Using carp hepatocytes, the possible involvement of JAK/STAT, MAPK, and PI3K/Akt cascades in GH-induced type II SOCS expression was examined. Using transfection

Published by Bioscientifica Ltd. 
studies in $\mathrm{CHO}$ cells, the effects of over-expression of grass carp type II SOCS on (i) $\mathrm{JAK}_{2} / \mathrm{STAT}_{5}$ signaling coupled to carp GH receptor (GHR) and (ii) GH-induced grass carp Igf1 promoter activity were also investigated. Our studies for the first time elucidate the post-receptor signaling for GH-induced type II SOCS expression at the hepatic level and provide evidence that Socs1-3 and Cish can act as feedback repressors for GH signaling and induction of igf1 gene transcription in the carp liver.

\section{Materials and methods}

\section{Animal and test substances}

One-year-old grass carp (Ctenopharyngodon idellus) with body weight $2.0-2.5 \mathrm{~kg}$ were obtained from local markets, housed in $250 \mathrm{~L}$ aquaria at $20^{\circ} \mathrm{C}$ under $12 \mathrm{~h}$ light: $12 \mathrm{~h}$ darkness photoperiod, and fed to satiation twice daily for at least 7 days before experimentation. As the fish at this stage were pre-pubertal and sexual dimorphism was not apparent, grass carp of mixed sexes were used for tissue sampling and hepatocyte preparation. During the process, the fish was killed by MS222 anesthesia (0.05\%; Sigma) followed by spinosectomy according to the protocol approved for animal use at the University of Hong Kong. Test substances, including porcine $\mathrm{GH}$, IL- $1 \beta$, TNF $\alpha$, lipopolysaccharide (LPS), $\mathrm{JAK}_{2}$ inhibitor 1,2,3,4,5,6-hexabromocyclohexane (HEX), STAT1 inhibitor fludarabine (FA), STAT 3 inhibitor ethyl-1-(cyano-2,3,5,6-tetrafluorophenyl)-6,7,8-trifluoro-4oxo-1,4-dihydroquinoline-3-carboxylate (ETDDC), STAT $_{5}$ inhibitor N1-(11H-Indolo[3,2-c]quinolin-6-yl)-N2,N2dimethylethane-1,2-diamine (IQDMA), $\mathrm{P}_{38}$ MAPK inhibitor PD169316, MEK $_{1 / 2}$ inhibitor U0126, PI3Kinhibitor LY294002, and protein kinase B (Akt) inhibitor 1L6-hydroxymethylchiro-inositol-2-O-methyl-3-O-octadecyl-sn-glycero carbonate (HIMOC), were obtained from Calbiochem. For transfection studies, the $\mathrm{JAK}_{2} / \mathrm{STAT}_{5}$-responsive $8 \times \mathrm{GHRE}$. LUC reporter and $\mathrm{STAT}_{5}$ expression vector $\mathrm{STAT}_{5}$.pcDNA were generous gifts from Peter S Rotwein (Oregon Health \& Science University, Portland, OR, USA).

\section{Molecular cloning, copy number, and tissue expression of Socs1-3 and Cish}

For molecular cloning of type II SOCS, total RNA was extracted from the carp liver and subjected to $5^{\prime} / 3^{\prime}$-RACE using primers designed based on zebrafish Socs1-3 and Cish. Sequence alignment, 3D protein modeling, and phylogenetic analysis were conducted using CLUSTAL-W, SWISS-MODEL, and MEGA 6.0 respectively. To deduce gene copy number of Socs1-3 and Cish, Southern blot was performed in genomic DNA isolated from carp blood (Lin et al. 2015). For tissue expression of type II SOCS, northern blot was conducted in total RNA prepared from the carp liver and pituitary, whereas RT-PCR was examined in selected tissues/brain areas using primers for respective gene targets with PCR conditions described in Table 1. Using LC/MS/MS, protein expression of Socs1-3 and Cish was also evaluated in the carp liver using a SCIEX TripleTOF-5600 system (AB SCIEX, Concord, ON, Canada) as described previously (Wong et al. 2013).

Table 1 Primer sequences and PCR conditions for RT-PCR of type II SOCS.

\begin{tabular}{|c|c|c|c|c|c|}
\hline \multirow{2}{*}{$\begin{array}{l}\text { Gene target/accession No } \\
\text { Primer sequence }\end{array}$} & \multicolumn{4}{|c|}{ PCR condition } & \multirow[b]{2}{*}{ Product size } \\
\hline & Denaturing & Annealing & Extension & Cycle no. & \\
\hline \multicolumn{6}{|l|}{ socs1/GU224284 } \\
\hline F: 5'-CAGCAGGCAGCCATTT-3' & $94^{\circ} \mathrm{C}$ & $49^{\circ} \mathrm{C}$ & $72^{\circ} \mathrm{C}$ & 35 & $232 b p$ \\
\hline R: 5'-GACCGTGTTGTCCTTTTGT-3' & $30 \mathrm{~s}$ & $30 \mathrm{~s}$ & $30 \mathrm{~s}$ & & \\
\hline \multicolumn{6}{|l|}{ socs2/GQ478990 } \\
\hline F: 5'-CGTCGGAGGGCACATTTC-3' & $94^{\circ} \mathrm{C}$ & $55^{\circ} \mathrm{C}$ & $72^{\circ} \mathrm{C}$ & 35 & $280 \mathrm{bp}$ \\
\hline R: 5'-CGGAGTCGTGAGCAGCAG-3' & $30 \mathrm{~s}$ & $30 \mathrm{~s}$ & $30 \mathrm{~s}$ & & \\
\hline \multicolumn{6}{|l|}{ socs3/EU625352 } \\
\hline F: 5'-GGTCCG AGATATGTTGAATGA-3' & $94^{\circ} \mathrm{C}$ & $55^{\circ} \mathrm{C}$ & $72^{\circ} \mathrm{C}$ & 35 & $240 \mathrm{bp}$ \\
\hline R: 5'-CAGTGTCTTGTATGACAAGGTGA-3' & $30 \mathrm{~s}$ & $30 \mathrm{~s}$ & $30 \mathrm{~s}$ & & \\
\hline \multicolumn{6}{|l|}{ cish/GU384205 } \\
\hline F: 5' - AGAGCTCATTTGCTGATACCT-3' & $94^{\circ} \mathrm{C}$ & $58^{\circ} \mathrm{C}$ & $72^{\circ} \mathrm{C}$ & 35 & $328 \mathrm{bp}$ \\
\hline R: 5'-GGAAACGTCCGAGACTGTACT-3' & $30 \mathrm{~s}$ & $30 \mathrm{~s}$ & $30 \mathrm{~s}$ & & \\
\hline \multicolumn{6}{|l|}{$\beta$-actin/M25013 } \\
\hline F: 5'-CTGGTATCGTGATGGACTCT-3' & $94^{\circ} \mathrm{C}$ & $56^{\circ} \mathrm{C}$ & $72^{\circ} \mathrm{C}$ & 30 & $285 b p$ \\
\hline R: 5'-AGCTCATAGC TCTTCTCCAG-3' & $30 s$ & $30 \mathrm{~s}$ & $30 s$ & & \\
\hline
\end{tabular}


Table 2 Primer sequences and PCR conditions for real-time PCR of target transcripts.

\begin{tabular}{|c|c|c|c|c|c|c|}
\hline \multirow{2}{*}{$\begin{array}{l}\text { Gene target } \\
\text { Primer sequence }\end{array}$} & \multicolumn{5}{|c|}{ PCR condition } & \multirow{2}{*}{$\begin{array}{c}\text { Product size and } \\
\text { Tm value }\end{array}$} \\
\hline & Denature & Anneal & Extension & Detection & Cycle no. & \\
\hline \multicolumn{7}{|l|}{ socs1 } \\
\hline F: 5'-CAGCAGGCAGCCATTT-3'; & $94^{\circ} \mathrm{C}$ & $49^{\circ} \mathrm{C}$ & $72^{\circ} \mathrm{C}$ & $80^{\circ} \mathrm{C}$ & 35 & $232 \mathrm{bp}$ and $83.1^{\circ} \mathrm{C}$ \\
\hline R: 5'-GACCGTGTTGTCCTTTGT-3' & $30 \mathrm{~s}$ & $30 \mathrm{~s}$ & $30 \mathrm{~s}$ & $20 \mathrm{~s}$ & & \\
\hline \multicolumn{7}{|l|}{$\operatorname{socs} 2$} \\
\hline F: 5'-CGTCGGAGGGCACATTTC-3' & $94^{\circ} \mathrm{C}$ & $55^{\circ} \mathrm{C}$ & $72^{\circ} \mathrm{C}$ & $82^{\circ} \mathrm{C}$ & 35 & $280 \mathrm{bp}$ and $86.1^{\circ} \mathrm{C}$ \\
\hline R: 5'-CGGAGTCGTGAGCAGCAG-3' & $30 \mathrm{~s}$ & $30 \mathrm{~s}$ & $30 \mathrm{~s}$ & $20 \mathrm{~s}$ & & \\
\hline \multicolumn{7}{|l|}{$\operatorname{socs} 3$} \\
\hline F: 5'-GGTCCG AGATATGTTGAATGA-3' & $94^{\circ} \mathrm{C}$ & $55^{\circ} \mathrm{C}$ & $72^{\circ} \mathrm{C}$ & $82^{\circ} \mathrm{C}$ & 35 & $240 \mathrm{bp}$ and $84.8^{\circ} \mathrm{C}$ \\
\hline R: 5'-CAGTGTCTTGTATGACAAGGTG-3' & $30 \mathrm{~s}$ & $30 \mathrm{~s}$ & $30 s$ & $20 s$ & & \\
\hline \multicolumn{7}{|l|}{ cish } \\
\hline F: 5'-AGAGCTCATTTGCTGATACCT-3' & $94^{\circ} \mathrm{C}$ & $58^{\circ} \mathrm{C}$ & $72^{\circ} \mathrm{C}$ & $84^{\circ} \mathrm{C}$ & 35 & $328 \mathrm{bp}$ and $85.2^{\circ} \mathrm{C}$ \\
\hline R: 5'-GGAAACGTCCGAGACTGTACT-3' & $30 \mathrm{~s}$ & $30 \mathrm{~s}$ & $30 s$ & $20 s$ & & \\
\hline \multicolumn{7}{|l|}{ igf1 } \\
\hline F: 5'-TCTCACTGGTGCTGTGCGTCCT-3' & $94^{\circ} \mathrm{C}$ & $65^{\circ} \mathrm{C}$ & $72^{\circ} \mathrm{C}$ & $84^{\circ} \mathrm{C}$ & 40 & $203 \mathrm{bp}$ and $87.5^{\circ} \mathrm{C}$ \\
\hline R: 5'-GCTCTGAAAGCAGCATTCGTCC-3' & $30 \mathrm{~s}$ & $30 \mathrm{~s}$ & $30 \mathrm{~s}$ & $20 \mathrm{~s}$ & & \\
\hline \multicolumn{7}{|l|}{185} \\
\hline F: 5'-AGCAACTTTAGTATACGCTATT-3' & $94^{\circ} \mathrm{C}$ & $64^{\circ} \mathrm{C}$ & $72^{\circ} \mathrm{C}$ & $79^{\circ} \mathrm{C}$ & 40 & $210 \mathrm{bp}$ and $85.0^{\circ} \mathrm{C}$ \\
\hline R: 5'-CTGAGAAACGGCTACCACATC-3' & $30 \mathrm{~s}$ & $30 \mathrm{~s}$ & $30 \mathrm{~s}$ & $20 s$ & & \\
\hline
\end{tabular}

\section{Measurement of socs1-3 and cish mRNA expression in carp hepatocytes}

Carp hepatocytes (with $>95 \%$ viability) were prepared by collagenase digestion (Reindl et al. 2011), seeded in 24-well plates at $\sim 0.7 \times 10^{6}$ cells $/ \mathrm{mL} /$ well at $28^{\circ} \mathrm{C}$, and challenged with test substances for the duration as indicated. Individual experiments were repeated with hepatocytes obtained from three to four cell preparation and each of them was conducted with quadruplicates in the same study. After treatment, total RNA (4 $\mu$ g/well, $\mathrm{OD}_{260 / 280}$ of 2 .0) was isolated, digested with DNase I, and subjected to real-time PCR according to the conditions described in Table 2 using a RotorGene-Q System (Qiagen). Serial dilutions of plasmid DNA with ORF of target genes were used as the standards for standard curve construction for data calibration using RotorGene Q-Rex software and parallel measurement of $18 S$ RNA was used as an internal control (for the details of cell preparation and experiments, see Supplemental Fig. 1, see section on supplementary data given at the end of this article).

\section{Western blot of post-receptor signaling targets in carp hepatocytes}

To examine GH action on JAK/STAT, MAPK, and PI3K/Akt cascades, Western blot was performed in carp hepatocytes after GH treatment as described previously (Jiang \& Wong 2013) with antibodies for the phosphorylated form and total protein of $\mathrm{MEK}_{1 / 2}(1: 1000), \mathrm{ERK}_{1 / 2}(1: 5000), \mathrm{P}_{38}$ MAPK (1:1000), Akt (1:1000), JAK 2 (1:1000), STAT $_{1}(1: 1000)$, STAT $_{3}$
(1:1000), and $\operatorname{STAT}_{5}(1: 1000)$ respectively (Cell Signaling). Parallel blotting of $\beta$-actin was used as the loading control.

\section{Functional expression of Socs1-3 and Cish in $\mathrm{CHO}$ cells}

To characterize the functionality of grass carp type II SOCS, the ORF of the respective gene targets was subcloned into pcDNA3.1 (Invitrogen) to generate the expression vectors for Socs1-3 and Cish respectively. To study the effects of type II SOCS on GH signaling, CHO cells with stable expression of grass carp GHR were used as the host cells for transient transfection of $8 \times \mathrm{GHRE}$. LUC, TK-Renilla (as internal control), and expression vectors for the respective type II SOCS with either GH treatment or co-transfection with $\mathrm{STAT}_{5}$.pcDNA by the protocol as described previously (Sun et al. 2014). In parallel studies, a $1.07 \mathrm{~kb}$ grass carp Igf1 promoter was cloned into the LUC reporter pGL3.basic and substituted for $8 \times$ GHRE.LUC in transfection study with $\mathrm{CHO}$ cells with $\mathrm{GH}$ treatment in the presence of $\mathrm{JAK}_{2} / \mathrm{STAT}_{5}$ inhibitors or co-transfection with the expression vectors for type II SOCS. After that, firefly and renilla luciferase activities expressed in CHO cells were measured using a Dual-Glo Luciferase Assay Kit (Promega).

\section{Data transformation and statistics}

Transcript expression of igf1, socs $1-3$, and cish was measured in terms of femtomole transcript detected $/ 10^{6}$ cells/well. As $18 S$ RNA did not exhibit notable changes

Published by Bioscientifica Ltd 
A Phylogenetic analysis of grass carp type II Socs

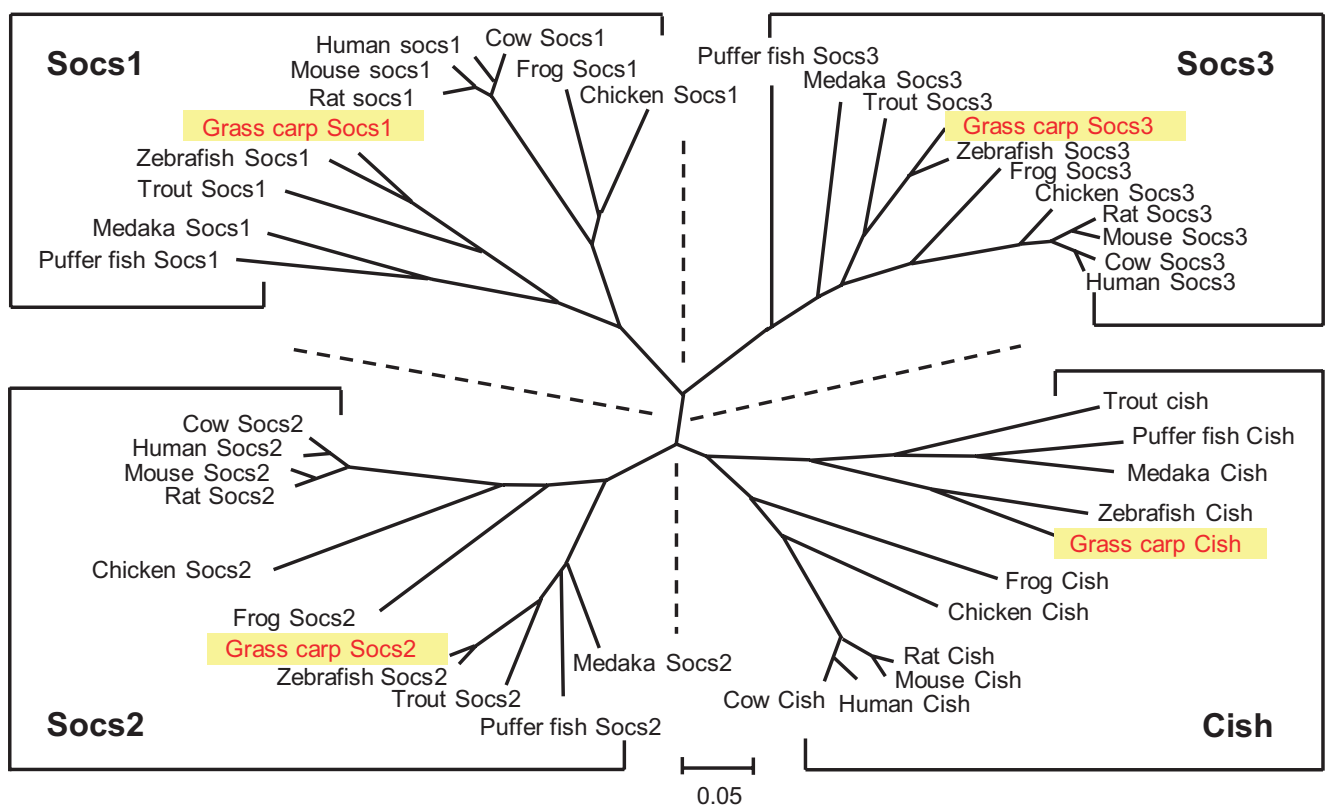

B

3D Protein Modeling of grass carp type II SOCS
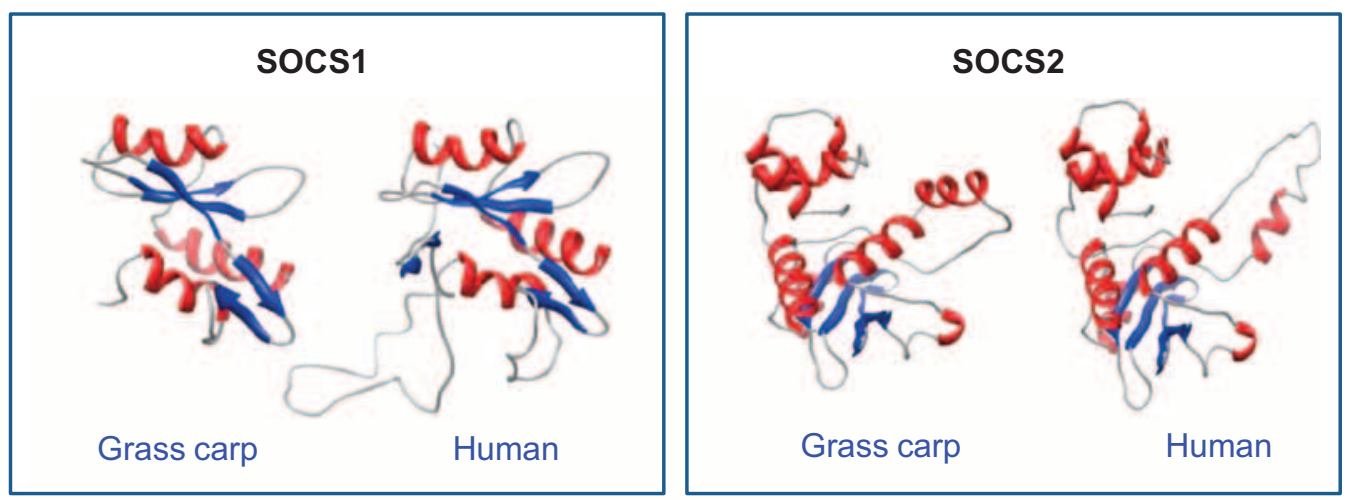

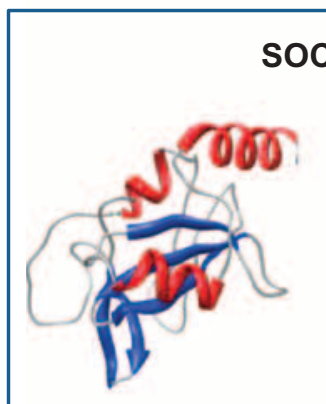

Grass carp

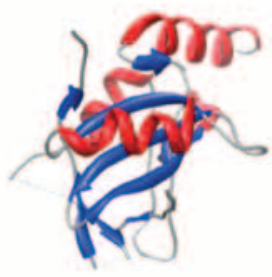

Human

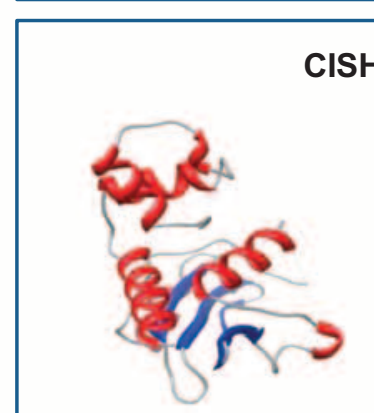

Grass carp

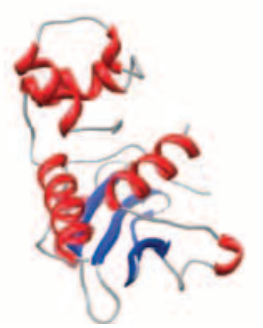

Human

Figure 1

Phylogenetic analysis and in silico protein modeling of grass carp Socs1-3 and Cish. (A) Unrooted analysis of the phylogenetic relationship of carp Socs 1-3 and Cish with the corresponding sequences identified in other vertebrates using neighbor-joining method by MEGA 6.0. The scale bar represents the evolutionary distance, and bootstrap values for individual nodes in the guide tree (in the range of $76-100 \%$ ) have been omitted for clarity. (B) Protein modeling of carp SOCS1-3 and CISH by SWISS-MODEL using crystal structures of their human counters as the templates. The $\alpha$-helixes (in red) and $\beta$-sheets (in blue) forming the SH2 domain and SOX box within the respective type II SOCS in grass carp were mapped according to the corresponding structures in human SOCS1-3 and CISH, respectively. 
A

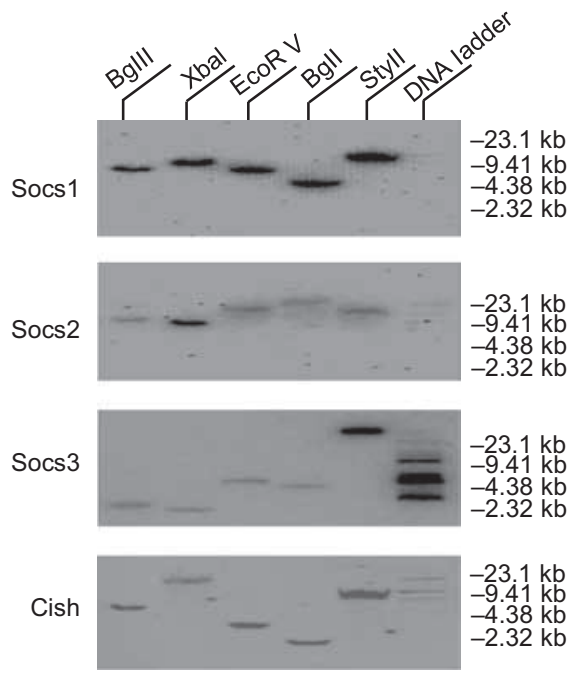

B

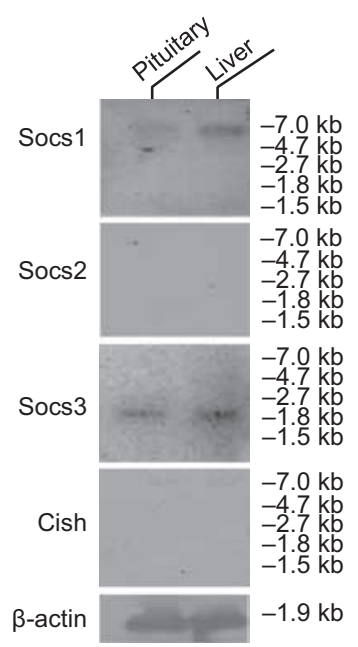

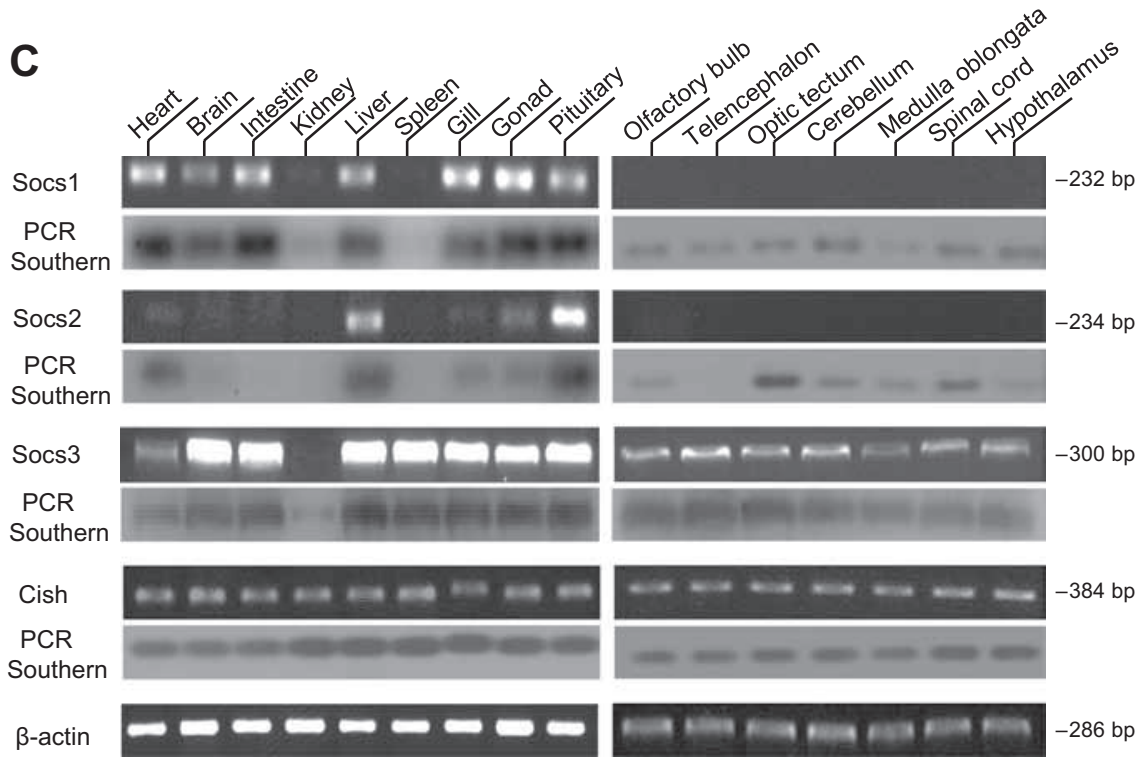

\section{Figure 2}

Gene copy number and tissue expression of Socs $1-3$ and Cish in grass carp. (A) Southern blot of Socs 1-3 and Cish using genomic DNA isolated from grass carp with digestion of restriction enzymes followed by hybridization with DIG-labeled probes for the respective targets of type II SOCS. (B) Northern blot of Socs1-3 and Cish using total RNA prepared from the carp pituitary and liver. Hybridization was performed with the probes used for Southern blot and parallel blotting of $\beta$-actin expression was used as the internal control. (C) Tissue expression profiling of Socs $1-3$ and Cish in grass carp by RT-PCR. Total RNA was prepared from selected tissues and brain areas and used for RT-PCR with primers specific for the respective gene targets. The authenticity of PCR products was confirmed by PCR Southern and RT-PCR for $\beta$-actin was used as the internal control. in our experiments, the raw data for target mRNA were simply transformed as a percentage of the mean value in control group (as '\%Ctrl'). For Western blot, signals detected by X-ray film were quantified by densitometry scanning and the ratio of phosphorylated form and total protein of respective kinases (as 'p:t ratio') was used as an index for their activation. For transfection studies, the raw data for firefly luciferase (in ALU) was normalized as a ratio of renilla luciferase data detected in the same sample. The normalized data were then expressed as fold increase compared with the mean value in the control group (as 'fold induction'). Data presented (mean \pm s.e.m.) were pooled from four experiments and analyzed by Student's $t$-test or ANOVA followed by Newman-Keuls test with difference considered as significant at $P<0.05$.

\section{Results}

\section{Molecular cloning, copy number, and tissue expression} of Socs1-3 and Cish

To establish the structural identity of type II SOCS in grass carp, full-length cDNAs for socs1-3 and cish were cloned in the carp liver (Supplemental Fig. 2), and phylogenetic analysis by neighbor-joining method revealed that these grass carp cDNAs could be grouped in the respective clades of type II SOCS with very close evolutionary relationship to the corresponding zebrafish sequences (Fig. 1A). The deduced protein sequences of grass carp Socs1-3 and Cish were found to be highly homologous to the respective targets in other vertebrates, especially in SH2 domain and SOCS box (also for KID \& ESS motifs in

Published by Bioscientifica Ltd. 
Socs1 and Socs3, Supplemental Fig. 3). Protein modeling also revealed that the spatial arrangement of $\alpha$-helical and $\beta$-sheet structures in the newly cloned Socs1-3 and Cish, which form the basis of SH2 domain and SOCS box, was highly comparable to their human counterparts (Fig. 1B).

As shown in Fig. 2A, Southern blot with carp genomic DNA digested with BgIII, Xbal, BgII, StyII, and EcoR V, respectively, consistently produced a single band after hybridization with the probes for the respective type II SOCS, implying that Socs1-3 and Cish are single-copy genes in carp genome. For tissue expression of type II SOCS, northern blot was performed in the carp liver and pituitary (Fig. 2B). In the two tissues examined, a single transcript of 7.0 and $1.8 \mathrm{~kb}$ in size were detected with the probes for Socs1 and Socs3, respectively; however, hybridization signals were not apparent for Socs 2 and Cish. Using RT-PCR, Socs3 and Cish signals were located ubiquitously in tissues including the gills, liver, kidney, gonad, intestine, spleen, pituitary, and heart as well as in brain areas including the olfactory bulbs, telencephalon, optic tectum, hypothalamus, cerebellum, medulla oblongata, and spinal cord (Fig. 2C). Similar findings were also noted for Socs1 and Socs2, except that Socs1 was not detected in the spleen and Socs 2 signals could not be identified in the kidney, intestine, spleen, and telencephalon.

To confirm that type II SOCS are also expressed at the protein level, LC/MS/MS was performed in trypsindigested lysate prepared from the carp liver (Supplemental Fig. 4A, B, C and D). Proteomic analysis of mass spectra of peptide fragments produced after trypsin digestion has revealed the presence of peptide products of grass carp type II SOCS (with 19 peptides for Socs1, 14 peptides for Socs2, 28 peptides for Socs3, and 23 peptides for Cish with confident level for target identification at $99 \%$ and protein coverage of respective type II SOCS ranging from 61.8 to $88.9 \%$ ), indicating that the socs $1-3$ and cish transcripts detected can be translated into respective proteins in the carp liver.

\section{Signal transduction for GH-induced type II SOCS mRNA expression in carp hepatocytes}

To examine type II SOCS expression at hepatic level, carp hepatocytes were used as a cell model, and treatment with IL- $1 \beta$ and TNF $\alpha$ or the endotoxin LPS was effective in elevating the mRNA levels of socs1-3 and cish in this cell culture system (Fig. 3A). In carp hepatocytes, GH treatment also induced igf 1 transcript expression with notable loss of Igf1 responsiveness at high dose $(1 \mu \mathrm{g} / \mathrm{mL}) /$ prolonged exposure ( $\geq 24 \mathrm{~h}$ ) to GH (Fig. 3B and C). As shown in Fig. 4A, GH could also up-regulate type II SOCS expression with different kinetics, with (i) transient rises in socs 1 and socs 3 mRNA levels peaked at $1 \mathrm{~h}$ after $\mathrm{GH}$ induction and (ii) gradual elevation of socs2 and cish mRNA levels up to $6 \mathrm{~h}$ or longer with GH exposure. By fixing the duration of $\mathrm{GH}$ treatment at $1 \mathrm{~h}$, increasing doses of GH (1-1000 ng/mL) were also found to stimulate socs1-3 and cish mRNA expression in a concentrationrelated fashion (Fig. 4B).

To elucidate the signal transduction mediating GH-induced type II SOCS expression, Western blot

A

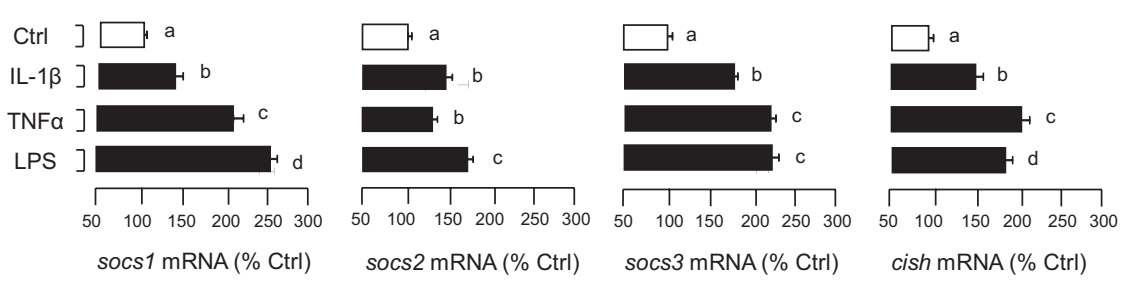

B

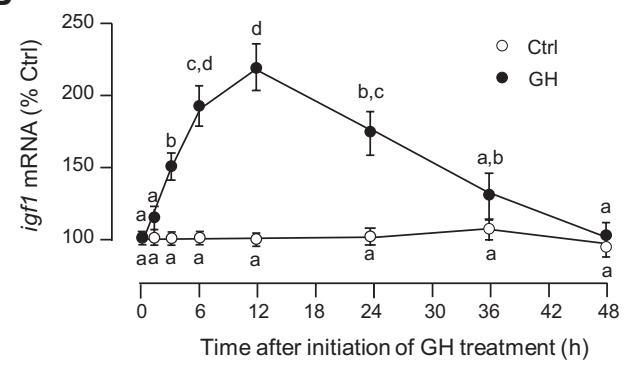

C

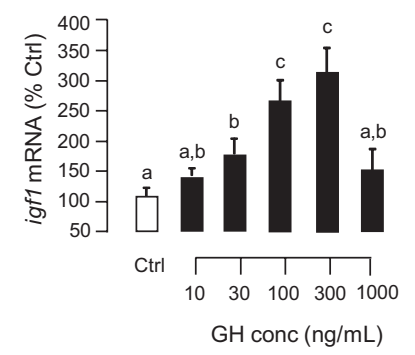

Figure 3

Target gene expression in carp hepatocytes with immune challenge and $\mathrm{GH}$ treatment. (A) Effects of immunological stimulants on type II SOCS mRNA expression in carp hepatocytes. In this experiment, hepatocytes were incubated for $6 \mathrm{~h}$ with IL- $1 \beta(0.1 \mu \mathrm{g} / \mathrm{mL}), \mathrm{TNF} \alpha(0.1 \mu \mathrm{g} / \mathrm{mL})$, and LPS $(1 \mu \mathrm{g} / \mathrm{mL})$ respectively. (B) Time course and (C) dose dependence of igf1 mRNA expression in carp hepatocytes with $\mathrm{GH}$ stimulation. The dose of $\mathrm{GH}$ treatment was fixed at $500 \mathrm{ng} / \mathrm{mL}$ for time-course study, whereas the duration of drug testing was fixed at $12 \mathrm{~h}$ for dose-dependence experiment. In these studies, static incubation of hepatocytes was performed with/without test substances. After that, total RNA was isolated and used for real-time PCR measurement of respective gene targets. Experimental groups denoted by different letters represent a significant difference at $P<0.05$ (ANOVA followed by Newman-Keuls test).
○ 2016 Society for Endocrinology Printed in Great Britain 
A
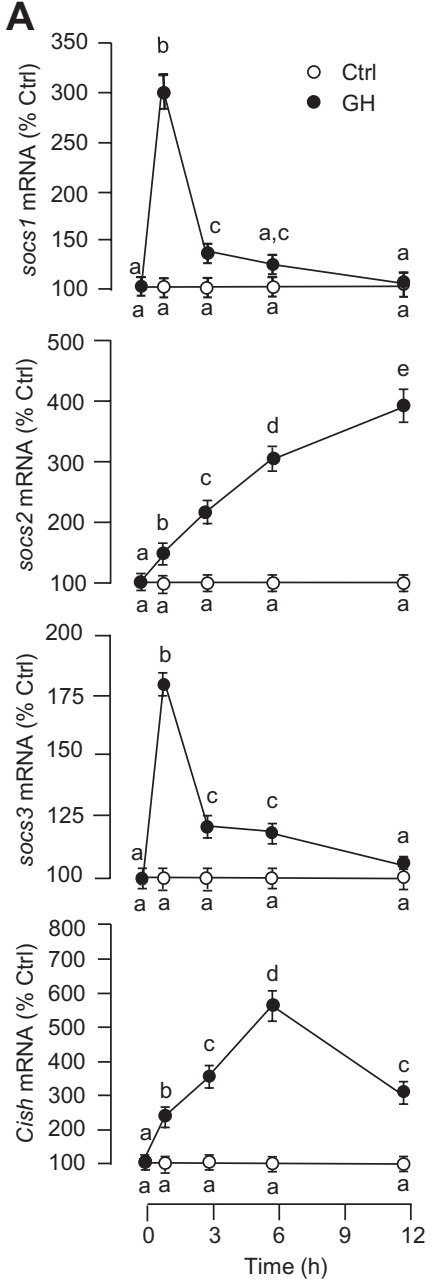

B
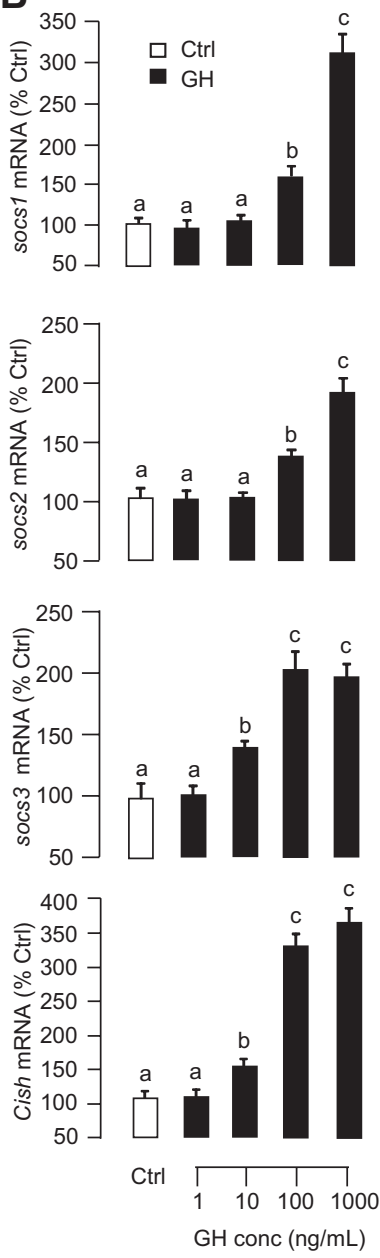

Figure 4

GH stimulation of type II SOCS mRNA expression in carp hepatocytes. (A) Time course and (B) dose dependence of GH treatment on Socs1-3 and cish mRNA expression in carp hepatocytes. The dose of GH was used at $500 \mathrm{ng} / \mathrm{mL}$ for the time course, whereas the duration of drug treatment was fixed at $1 \mathrm{~h}$ for dose-dependent study. After treatment, total RNA was extracted and subjected to real-time PCR for socs1-3 and cish mRNA measurement. Groups denoted by different letters represent a significant difference at $P<0.05$ (ANOVA followed by Newman-Keuls test).

was conducted in carp hepatocytes to test whether GH stimulation could activate the JAK/STAT pathway. As shown in Fig. 5A, GH treatment induced rapid phosphorylation of $\mathrm{JAK}_{2}, \mathrm{STAT}_{1}, \mathrm{STAT}_{3}$, and $\mathrm{STAT}_{5}$ with the highest responses observed for $\mathrm{STAT}_{5}$ (close to 40 -fold increase). In parallel studies, hepatocytes were challenged with GH with simultaneous treatment of the $\mathrm{JAK}_{2}$ inhibitor HEX, STAT ${ }_{1}$ inhibitor FA, $\mathrm{STAT}_{3}$ inhibitor ETDDC, or $\mathrm{STAT}_{5}$ inhibitor IQDMA (Fig. 5B). In these cases, GH-induced socs1-3 and cish mRNA expression was either attenuated or negated by the inhibitors targeting $\mathrm{JAK}_{2} /$ STATs pathway. In carp hepatocytes, a 10-min exposure

to $\mathrm{GH}$ was found to induce $\mathrm{MEK}_{1 / 2}, \mathrm{ERK}_{1 / 2}, \mathrm{P}_{38} \mathrm{MAPK}$, and Akt phosphorylation (Fig. 6A). Co-treatment with the MEK $_{1 / 2}$ inhibitor U0126 or $\mathrm{P}_{38}$ MAPK inhibitor PD169316 also reduced or abolished GH-induced socs1-3 and cish mRNA expression. Treatment with the PI3K inhibitor Ly294002 or Akt inhibitor HIMOC, interestingly, could inhibit GH-induced socs 3 mRNA expression but had no effects on the corresponding responses of other type II SOCS (Fig. 6B).

\section{Socs 1-3 and Cish expression on GHR signaling via $\mathrm{JAK}_{2} / \mathrm{STAT}_{5}$ pathway}

As the pharmacological tools for SOCS are not yet available, a molecular approach was used to examine Socs1-3 and Cish expression on GHR signaling in grass carp. In CHO cells with grass carp GHR expression and transfection with the $\mathrm{JAK}_{2} / \mathrm{STAT}_{5}$-responsive reporter $8 \times \mathrm{GHRE}$.LUC, GH treatment could induce luciferase activity expression and this effect was suppressed by co-treatment with the $\mathrm{JAK}_{2}$ inhibitor HEX or $\mathrm{STAT}_{5}$ inhibitor IQDMA (Fig. 7). In this cell model, transfection with increasing levels of the respective expression vectors for carp Socs $1-3$ and Cish also induced a dose-dependent inhibition on basal as well as GH-induced luciferase activity expression (Fig. 8A). To test whether the effects of type II SOCS were mediated by targeting $\mathrm{STAT}_{5}$ signaling, $\mathrm{STAT}_{5}$ over-expression by transfection with $\mathrm{STAT}_{5}$.pcDNA was performed (Fig. 8B). In this case, a significant rise in luciferase activity expression was noted with $\mathrm{STAT}_{5}$.pcDNA transfection and this stimulatory action was reduced dose dependently by over-expression of carp Socs1-3 and Cish respectively. Consistent with the role of $\mathrm{JAK}_{2} / \mathrm{STAT}_{5}$ in GHR signaling, the effect of $\mathrm{STAT}_{5}$ over-expression on luciferase activity was markedly enhanced by GH, and again, this potentiating effect was also sensitive to the inhibition by over-expression of type II SOCS (Fig. 8C).

\section{Socs1-3 and Cish expression on GH-induced Igf1 promoter activity}

In $\mathrm{CHO}$ cells with GHR expression, Igf1 promoter activity was examined by transfection with the pGL3.basic reporter carrying a $1.07 \mathrm{~kb}$ grass carp Igf1 promoter. In this case, luciferase activity mediated by Igf1 promoter could be induced by GH treatment, and this stimulation was blocked by co-treatment with the $\mathrm{JAK}_{2}$ inhibitor HEX (Fig. 9A) or $\mathrm{STAT}_{5}$ inhibitor IQDMA (Fig. 9B). Similar to the preceding studies with the $\mathrm{JAK}_{2} / \mathrm{STAT}_{5}$-responsive 
A

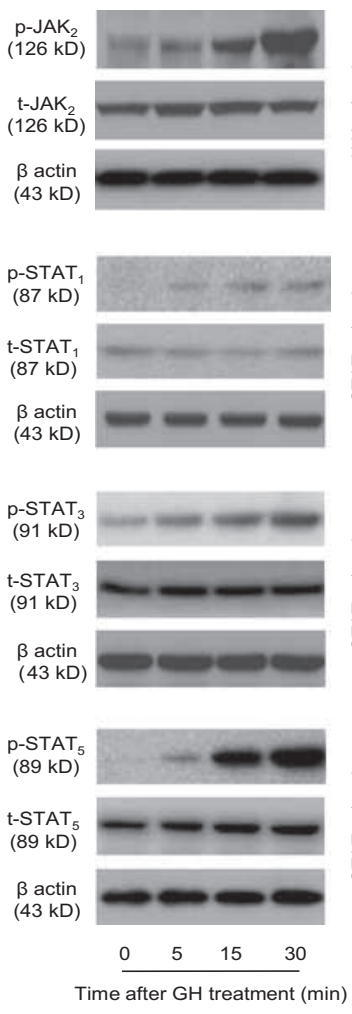

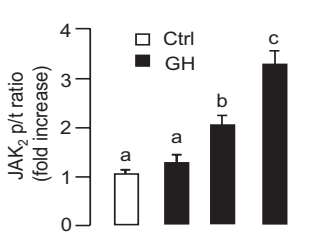
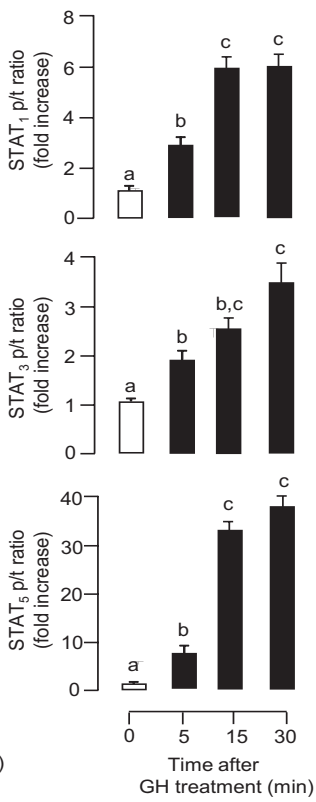

B
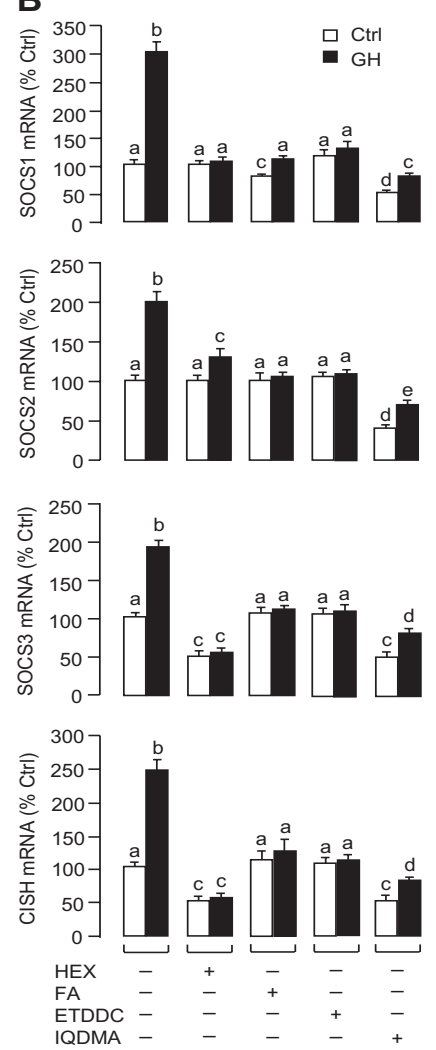

Figure 5

JAK/STAT pathway in GH-induced type II SOCS mRNA expression in carp hepatocytes. (A) GH stimulation of $\mathrm{JAK}_{2}, \mathrm{STAT}_{1}, \mathrm{STAT}_{3}$, and $\mathrm{STAT}_{5}$ phosphorylation. Cell lysate was harvested from hepatocytes after $\mathrm{GH}$ treatment $(500 \mathrm{ng} / \mathrm{mL})$ up to $30 \mathrm{~min}$ and used for Western blot for

phosphorylated form ('p-') and total protein ('t-') of the respective signaling targets. Parallel blotting of $\beta$-actin was used as internal control and activation status of signaling target was quantified as the ratio of $p$ - and $t$ - form of the same protein (as 'p:t ratio'). (B) Blocking JAK/STAT pathway on GH-induced socs1-3 and cish mRNA expression. Hepatocytes were incubated with $\mathrm{GH}(500 \mathrm{ng} / \mathrm{mL})$ for $1 \mathrm{~h}$ with/ without co-treatment of $\mathrm{JAK}_{2}$ inhibitor $\mathrm{HEX}(50 \mu \mathrm{M})$, $\mathrm{STAT}_{1}$ inhibitor FA $(50 \mu \mathrm{M})$, STAT $_{3}$ inhibitor ETDDC $(300 \mathrm{nM})$, and STAT $_{5}$ inhibitor IQDMA $(50 \mu \mathrm{M})$ respectively. After that, total RNA was isolated and used for real-time PCR measurement of socs1-3 and cish mRNA expression. reporter $8 \times$ GHRE.LUC, both basal and GH-induced luciferase activity expression mediated by Igf1 promoter could be reduced or negated in a dose-related fashion by co-transfection with increasing levels of the expression vectors for grass carp type II SOCS (Fig. 9C, D, E and F).

\section{Discussion}

As a first step to study the role of type II SOCS in GH functions in carp model, Socs1-3 and Cish were cloned in grass carp, and phylogenetic analysis of their cDNA sequences has confirmed that they could be clustered in the clades of respective subfamilies of type II SOCS. As revealed by sequence alignment and protein modeling, the protein structures of Socs1-3 and Cish were found to be highly conserved, especially in the $\mathrm{SH} 2$ domain and SOCS box. The spatial arrangement of $\beta$-sheets and $\alpha$-helixes forming the two domains in carp Socs1-3 and Cish is highly comparable with their human counterparts. In mammals, SH2 domain is a target recognition motif commonly found in tyrosine kinases and involved in protein-protein interaction with phosphotyrosine residues (Machida \& Mayer 2005). Previous studies (e.g., in hepatocytes and lymphocytes) have shown that $\mathrm{SH} 2$ domain in SOCS proteins is essential for their association with $\mathrm{JAK}_{2}$ (Machida \& Mayer 2005, Liu et al. 2006) and can compete with $\mathrm{STAT}_{5}$ binding for cytokine receptors to inhibit $\mathrm{JAK}_{2} / \mathrm{STAT}_{5}$ signaling (Hilton 1999). Similar to SH2 domain, SOCS box also plays a role in SOCS inhibition of cytokine signaling as it can interact with elongin B/C, culin B, and Ring-box 2 to form a complex with E3 ubiquitin ligase activity (Yoshimura et al. 2007) and trigger proteasomal degradation of $\mathrm{JAK}_{2}$ by SOCS binding (Piessevaux et al. 2008a). The presence of structural motifs in grass carp Socs1-3 and Cish for signal termination of JAK/STAT pathway raises the possibility that the type II SOCS in fish model may also participate in the down-regulation of cytokine signaling in a way similar to mammals.

As revealed by genomic Southern blot, the newly cloned type II SOCS are confirmed to be single-copy genes in the carp genome. Expression profiling using RT-PCR also reveals that Socs1-3 and Cish are widely expressed at tissue level as well as in various brain areas in grass carp. Although the four type II SOCS could all be located in the liver and pituitary by RT-PCR, northern blot signals for the respective transcripts were detected only for Socs1 $(7.0 \mathrm{~kb})$ and Socs3 $(1.8 \mathrm{~kb})$ but not Socs 2 and Cish, suggesting that Socs1 and Socs3 are the major forms of type II SOCS expressed in these two tissues. Recently, tissue expression

Published by Bioscientifica Ltd 
A
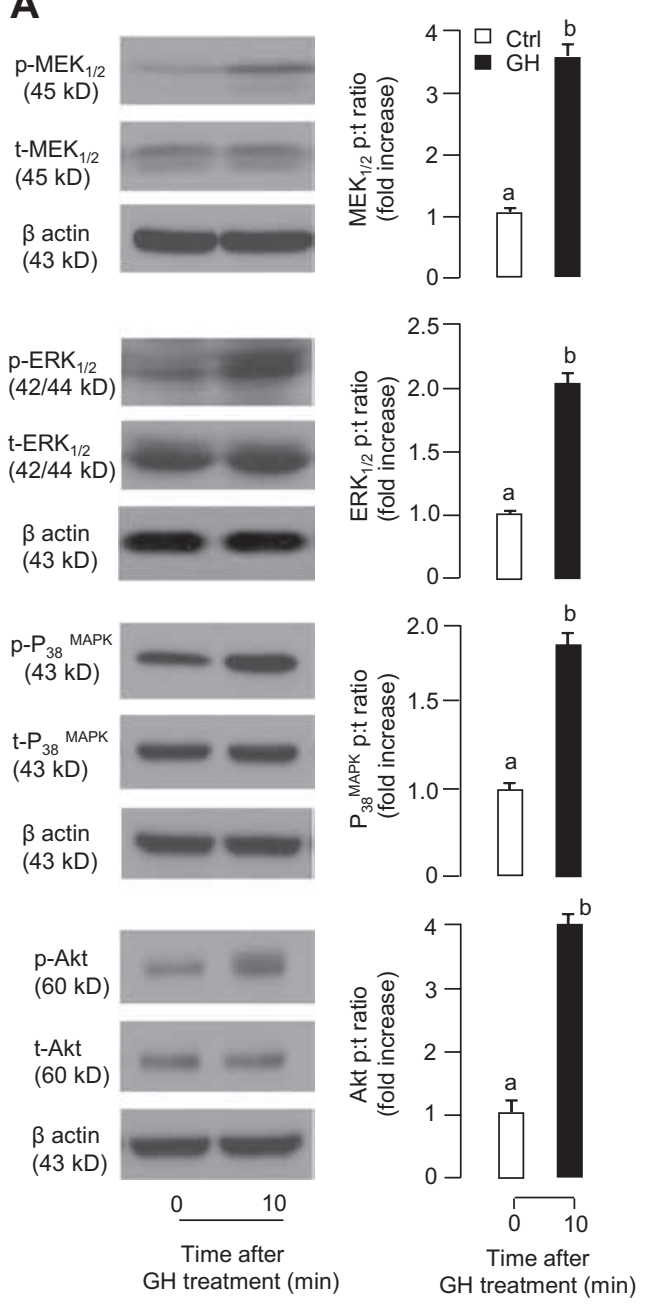

B
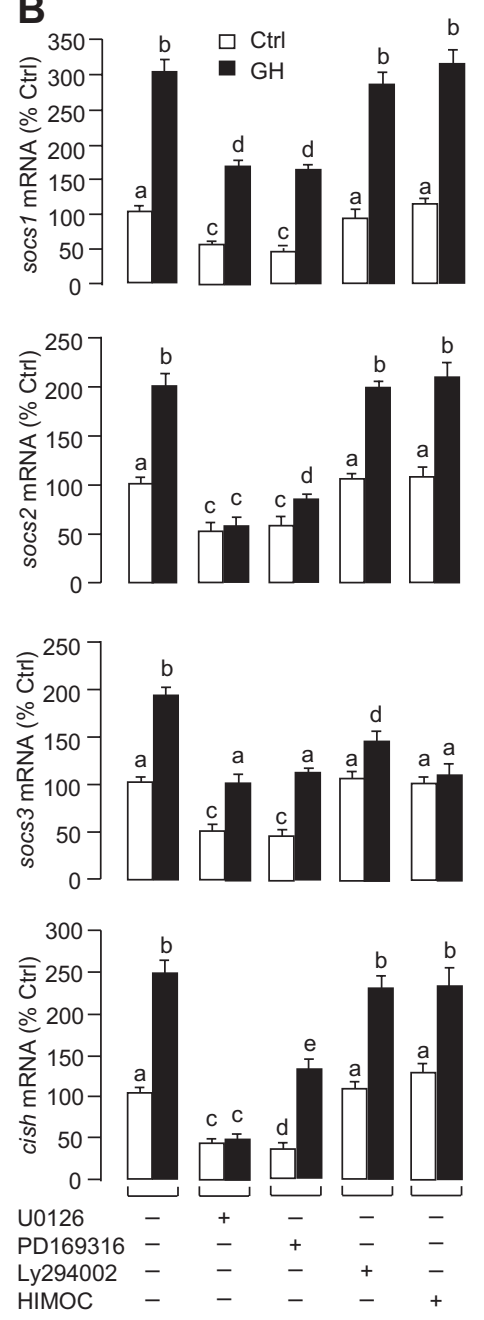

\section{Figure 6}

MAPK and PI3K/Akt pathways in GH-induced type II SOCS mRNA expression in carp hepatocytes. (A) GH stimulation of $\mathrm{MEK}_{1 / 2}, \mathrm{ERK}_{1 / 2}, \mathrm{P}_{38}$ MAPK, and Akt phosphorylation. Cell lysate was harvested from hepatocytes after 10-min treatment of GH $(500 \mathrm{ng} / \mathrm{mL})$ and used for Western blot for phosphorylated form ('p-') and total protein ('t-') of the respective signaling targets. Parallel blotting of $\beta$-actin was used as internal control and activation status of signaling target was quantified as the ratio of $\mathrm{p}$ - and $\mathrm{t}$ - form of the same protein (as ' $p: t$ ratio'). (B) Blocking MAPK and PI3K/Akt pathways on GH-induced socs1-3 and cish mRNA expression. Hepatocytes were challenged with $\mathrm{GH}(500 \mathrm{ng} / \mathrm{mL})$ for $1 \mathrm{~h}$ with/ without co-treatment of the $\mathrm{MEK}_{1 / 2}$ inhibitor U0126 $(10 \mu \mathrm{M}), \mathrm{P}_{38}$ MAPK inhibitor PD169316 $(10 \mu \mathrm{M})$, PI3K inhibitor Ly294002 $(10 \mu \mathrm{M})$, and Akt inhibitor HIMOC $(20 \mu \mathrm{M})$ respectively. After that, total RNA was isolated and subjected to real-time $\mathrm{PCR}$ for quantitation of the respective transcripts of type II SOCS. of SOCS has also been reported in fish models, including salmon (Skjesol et al. 2014), yellow perch (Shepherd et al. 2012), rainbow trout (Wang \& Secombes 2008, Wang et al. 2010), puffer fish (Jin et al. 2007), and turbot (Zhang et al. 2011). Similar to grass carp, SOCS expression was found to be widely expressed, e.g., in the gills, spleen, gut, liver, kidney, muscle, and brain. However, species-specific variations could still be noted. For examples, in rainbow trout, notable levels of SOCS and Cish gene expression could be located in the spleen and kidney with little/low levels of signal found in the liver (Wang \& Secombes 2008, Wang et al. 2010). This is different from grass carp, in which Socs $1-3$ and Cish were readily detectable in the liver; however, Socs 1 and Socs 2 signals in the spleen and kidney were low/undetectable. The different patterns of type II SOCS expression observed suggest that the functional dominance of individual SOCS may vary at the tissue level among different species. In mammals, hepatic expression of SOCS has also been reported and found to have tumor suppressor activity (Miyoshi et al. 2005) and modulatory effects on liver regeneration (Brand et al. 2007). However, the biological actions of SOCS in the liver of fish species have yet to be characterized.

In mammals, up-regulation of SOCS expression is well documented after microbial/viral infection or cytokine treatment (Strebovsky et al. 2012), and these SOCS responses constitute an intracellular feedback to turn off/tune down cytokine signaling via the JAK/ STAT pathway and prevent overshot of proinflammatory activities (Tamiya et al. 2011). Cytokine induction of SOCS can not only be found in immune tissues but also be found in the liver (Tollet-Egnell et al. 1999). The liver not only represents a key component of the somatotropic axis but also an immunological organ for antigen presentation, NK/T cell priming, and production of complement factors (Racanelli \& Rehermann 2006). In this study, Socs1-3 and Cish expression, both for transcripts (by RT-PCR \& real-time PCR) and proteins (by

Published by Bioscientifica Ltd 
A

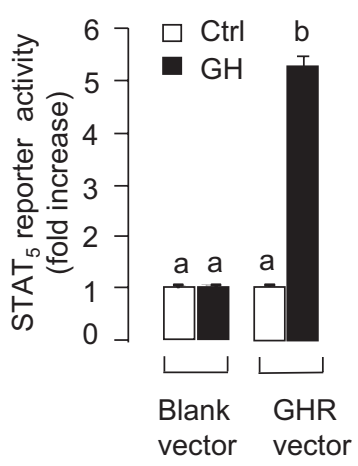

B

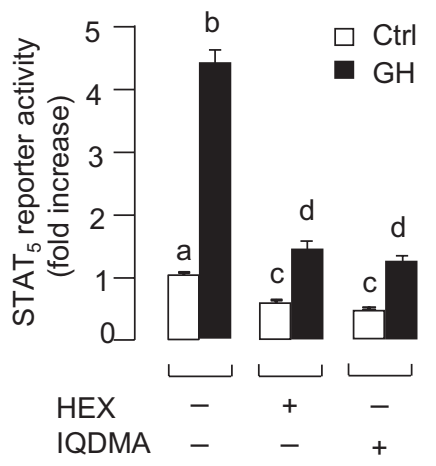

Figure 7

$\mathrm{JAK}_{2} / \mathrm{STAT}_{5}$ pathway coupled to carp GHR. (A) Functional expression of carp GHR in CHO cells. Stable transfection of $\mathrm{CHO}$ cells with the expression vector for grass carp GHR was performed (with parallel transfection of the blank vector as a control). After the line of $\mathrm{CHO}$ cells with GHR expression was selected, transient transfection with the $\mathrm{JAK}_{2} /$ STAT $_{5}$-responsive reporter $8 \times$ GHRE. LUC was conducted and GHR activation was induced by $\mathrm{GH}$ treatment $(500 \mathrm{ng} / \mathrm{mL})$ for $24 \mathrm{~h}$. (B) Blocking $\mathrm{JAK}_{2} / \mathrm{STAT}_{5}$ pathway in $\mathrm{STAT}_{5}$ signaling via GHR expressed in $\mathrm{CHO}$ cells. In $\mathrm{CHO}$ cells with GHR expression, transient transfection with the $\mathrm{STAT}_{5}{ }^{-}$ responsive LUC reporter was performed followed by $\mathrm{GH}$ induction $(500 \mathrm{ng} / \mathrm{mL})$ for $24 \mathrm{~h}$ with co-treatment of $\mathrm{JAK}_{2}$ inhibitor $\mathrm{HEX}(50 \mu \mathrm{M})$ or $\mathrm{STAT}_{5}$ inhibitor IQDMA $(50 \mu \mathrm{M})$. In these studies, cell lysate was prepared after drug treatment and used for luciferase activity measurement as described in 'Materials and methods' section.

LC/MS/MS), have been confirmed in the carp liver, and mRNA levels of these type II SOCS could be increased in carp hepatocytes by LPS exposure or treatment with IL-1 $\beta$ and TNF $\alpha$. These findings indicate that hepatic expression of type II SOCS could be induced by endotoxin and cytokines, which may serve as feedback repressors for immune responses occurring in the carp liver. In fish models, LPS/cytokine-induced socs1-3 gene expressions have been reported in the head kidney of puffer fish (Jin et al. 2007) and trout monocytes/macrophages (Wang \& Secombes 2008), corroborating with the idea that the role of SOCS as signal terminators for cytokine actions is well conserved in vertebrate evolution (Wang et al. 2011). In carp hepatocytes, GH consistently induced igf1 mRNA expression in a time- and dose-dependent manner. Of note, down-regulation of Igf1 responses was also observed with high concentration/prolonged exposure to $\mathrm{GH}$, suggesting the presence of intrinsic mechanisms to turn off/tune down GH signaling. As socs1-3 and cish mRNA expression could be elevated by $\mathrm{GH}$ treatment in carp hepatocytes and these stimulatory effects occurred before/ during Igf1 down-regulation with prolonged incubation with $\mathrm{GH}$, the possible involvement of type II SOCS in signal termination for GH-induced Igf1 expression cannot be excluded. In rodents, hepatic expression of Socs2-3

and Cish can be induced by GH both in vivo and in vitro (Tollet-Egnell et al. 1999, Greenhalgh \& Alexander 2004) and deregulation of GH signaling by Socs1-3 has been reported in cell lines, e.g., F442A fibroblasts (Greenhalgh \& Alexander 2004). However, direct evidence showing SOCS inhibition of GH-induced Igf1 expression has not been documented.

Although the signal transduction for GH-induced SOCS/CISH expression at the hepatic level is still unknown, Socs2 interaction with GHR (Greenhalgh et al. 2002a) and Socs 1 and Socs 3 inhibition of $\mathrm{JAK}_{2}$ activation (Hansen et al. 1999) and GH-responsive promoters (Adams et al. 1998) have been reported in various cell models. Recently, down-regulation of GH signaling by SOCS2 via SOCS boxdependent ubiquitination and proteasomal degradation of GHR has been demonstrated in mouse liver (Vesterlund et al. 2011). In our studies, GH treatment induced rapid phosphorylation of $\mathrm{JAK}_{2}, \mathrm{STAT}_{1}, \mathrm{STAT}_{3}, \mathrm{STAT}_{5}, \mathrm{MEK}_{1 / 2}$, ERK $_{1 / 2}$, and $\mathrm{P}_{38}$ MAPK in carp hepatocytes. Furthermore, GH-induced socs1-3 and cish mRNA expression was also sensitive to the blockade of $\mathrm{JAK}_{2}$ (by HEX), $\mathrm{STAT}_{1}$ (by FA), $\mathrm{STAT}_{3}$ (by ETDDC), $\mathrm{STAT}_{5}$ (by IQDMA), MEK ${ }_{1 / 2}$ (by U0126), and $\mathrm{P}_{38}$ MAPK (by PD169316), implying that $\mathrm{GH}$-induced type II SOCS expression in the carp liver is mediated by $\mathrm{JAK}_{2} /$ STATs and MAPK cascades. Although Akt phosphorylation was also noted after GH induction, except for the drop in transcript level for socs3, GH-induced socs1-2, and cish mRNA expression were not affected by blocking PI3K (by Ly294002) or Akt (by HIMOC). Apparently, the PI3K/Akt pathway is involved in GH-induced socs3, but not socs1-2 and cish gene expression. Our results are consistent with GHR coupling to $\mathrm{JAK}_{2} /$ STATs, MAPK, and PI3K/Akt signaling reported in mammals (Miquet et al. 2010). Recently, GH activation of $\mathrm{STAT}_{5}, \mathrm{ERK}_{1 / 2}$, and Akt and their involvement in GH-induced Igf1 expression have also been demonstrated in trout hepatocytes (Reindl et al. 2011). To our knowledge, our study represents the first report to elucidate the postreceptor signaling for GH-induced type II SOCS expression at the hepatic level.

In mammals, SOCS expression induced by cytokines is known to inhibit STAT $_{5}$ activation as well as transcription of STAT $_{5}$-responsive genes, e.g., ALS and Spi-2.1 genes (Adams et al. 1998, Boisclair et al. 2000). As the $\mathrm{JAK}_{2} / \mathrm{STAT}_{5}$ pathway is also a key component of the post-receptor signaling for GH-induced Igf1 expression at the hepatic level (Choi \& Waxman 2000, Davey et al. 2001), it would be logical to assume that SOCS expression could also down-regulate GH-induced igf1 gene transcription via interference of $\mathrm{JAK}_{2} / \mathrm{STAT}_{5}$ signaling. In $\mathrm{CHO}$ cells

Published by Bioscientifica Ltd. 
A
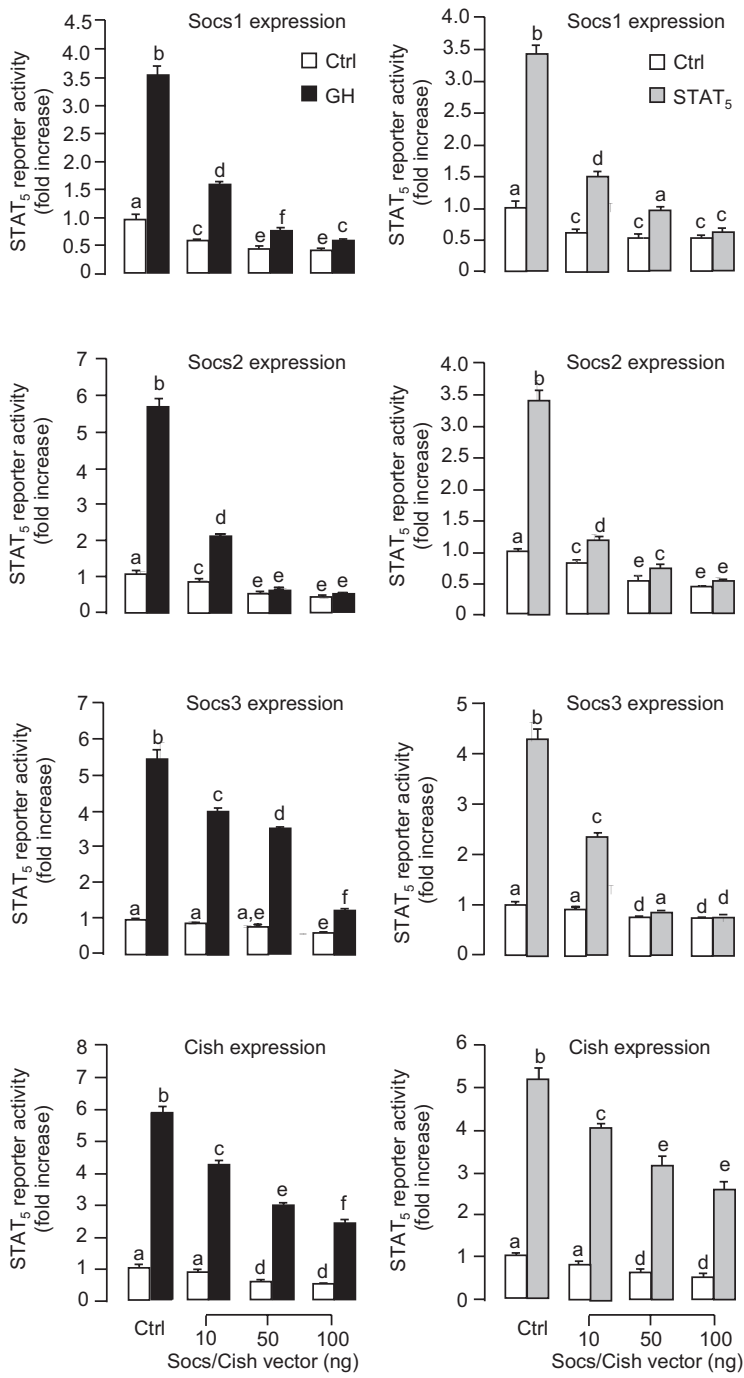

B
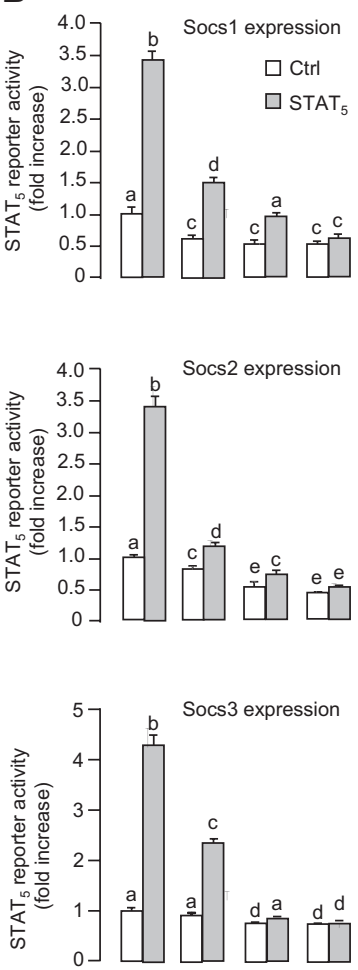

with the expression of carp GHR, GH treatment or $\mathrm{STAT}_{5}$ over-expression was effective in activating a $\mathrm{JAK}_{2} / \mathrm{STAT}_{5}-$ responsive reporter with GHR-responsive elements in its $5^{\prime}$ promoter and the stimulatory effect by GH could be markedly enhanced by STAT $_{5}$ over-expression. These stimulatory actions, however, could be dose dependently suppressed by over-expression of grass carp Socs1-3 and Cish. As GH activation of the $\mathrm{JAK}_{2} / \mathrm{STAT}_{5}$-responsive reporter could be consistently inhibited by blocking $\mathrm{JAK}_{2}$ (by HEX) and STAT $_{5}$ (by IQDMA) in our system, our results suggest that type II SOCS expression in carp model can inhibit $\mathrm{JAK}_{2} / \mathrm{STAT}_{5}$ signaling coupled to GHR. Our findings are comparable to the previous studies in 3T3-F442A cells, in which GH-induced activation of $\mathrm{STAT}_{5}$-responsive Spi-2.1 promoter could be negated by Socs 1 and Socs3 over-expression (Adams et al. 1998). To examine the role of type II SOCS on GH-induced Igf1 expression in fish

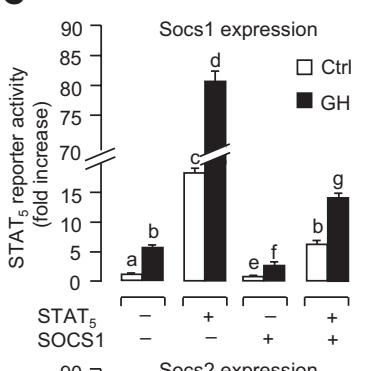

Socs2 expression
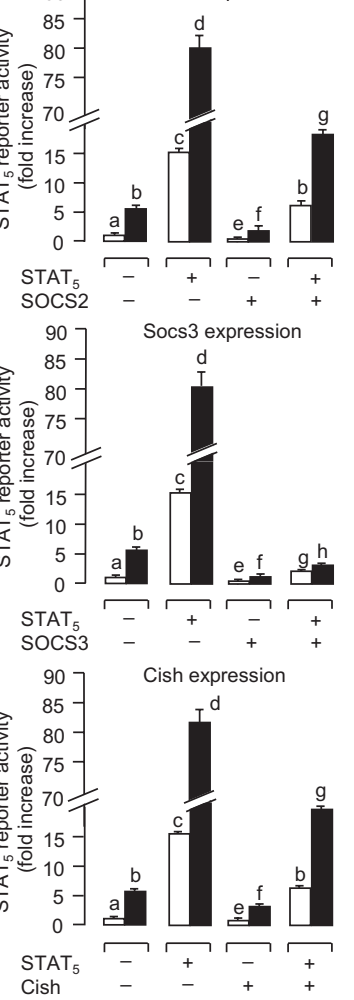

Figure 8

Type II SOCS expression on $\mathrm{JAK}_{2} / \mathrm{STAT}_{5}$ signaling via carp GHR. CHO cells with GHR expression were transfected with $\mathrm{JAK}_{2} / \mathrm{STAT}_{5}$-responsive reporter $8 \times$ GHRE.LUC with/without co-transfection of increasing amount of the expression vectors for carp Socs $1-3$ and Cish respectively. Treatment was initiated for $24 \mathrm{~h}$ with (A) static incubation with $\mathrm{GH}(500 \mathrm{ng} / \mathrm{mL})$, (B) over-expression of STAT ${ }_{5}$ by co-transfection with $\mathrm{STAT}_{5}$ expression vector, and (C) $\mathrm{STAT}_{5}$ over-expression with $\mathrm{GH}$ treatment $(500 \mathrm{ng} / \mathrm{mL})$. After that, cell lysate was prepared from $\mathrm{CHO}$ cells and assayed for luciferase activity as an index for $\mathrm{JAK}_{2} / \mathrm{STAT}_{5}$ reporter activation as described in 'Materials and methods' section. model, the full gene of grass carp igf 1 was cloned and a well-conserved $\mathrm{STAT}_{5}$ binding site was mapped in close proximity to a HNF1 $\alpha$ binding site located in its proximal promoter region (A O L Wong \& W W Wong, unpublished data). Similar bipartite pattern of $\mathrm{STAT}_{5}$ and HNF1 $\alpha$ binding sites has also been reported in Igf1 promoter of common carp (Vong et al. 2003) and salmon (Moghadam et al. 2007), implying that gene transcription of igf 1 in fish models is also responsive to $\mathrm{STAT}_{5}$ signaling. This idea is also consistent with our studies in $\mathrm{CHO}$ cells with GHR expression transfected with a luciferase-expressing reporter carrying the $1.07 \mathrm{~kb}$ grass carp Igf1 promoter. In this case, GH-induced Igf1 promoter activity could be reduced or negated by inhibiting $\mathrm{JAK}_{2}$ (by HEX) or $\mathrm{STAT}_{5}$ (by IQDMA), implying that $\mathrm{JAK}_{2} / \mathrm{STAT}_{5}$ pathway is involved in GH-induced igf1 gene transcription in carp model. Similar to our studies with JAK2/STAT5 reporter, 
A
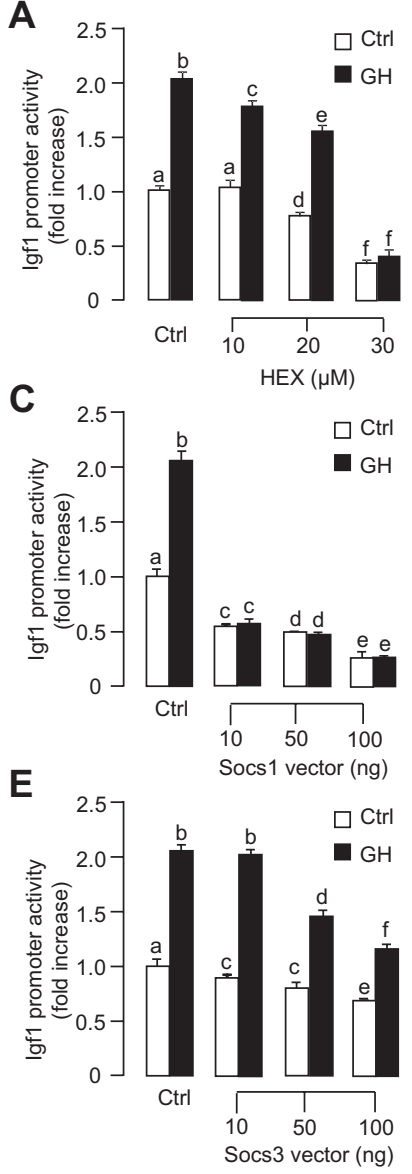

B

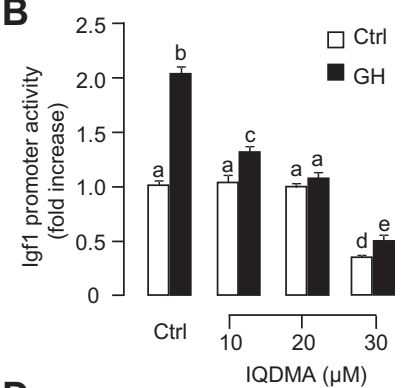

D

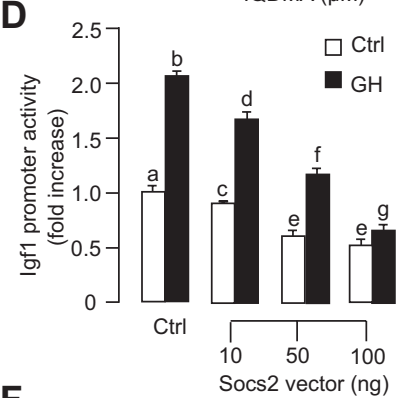

$\mathbf{F}$

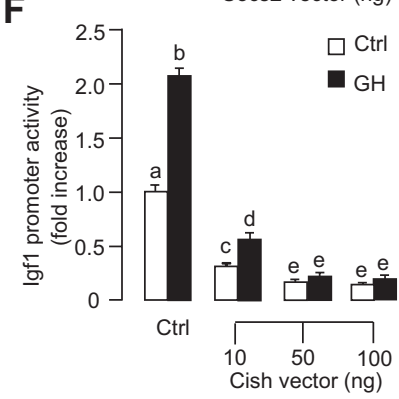

Figure 9

Type II SOCS expression on Igf1 promoter activation via JAK ${ }_{2} / \mathrm{STAT}_{5}$ signaling coupled to GHR. CHO cells with GHR expression were transfected with pGL3.basic carrying the $5^{\prime}$ promoter of grass carp igf1 gene. The cells were then challenged with $\mathrm{GH}(500 \mathrm{ng} / \mathrm{mL})$ in the presence of (A) the $\mathrm{JAK}_{2}$ inhibitor HEX, (B) the STAT inhibitor IQDMA, or (C, D, E and $\mathrm{F}$ ) with co-transfection of increasing amount of the expression vectors for carp Socs 1-3 and Cish respectively. After 24-h treatment, lysate was prepared from $\mathrm{CHO}$ cells and assayed for luciferase activity as an index for Igf1 promoter activation as described in 'Materials and methods' section.

both basal and GH-induced Igf1 promoter activity could be suppressed in a dose-related manner by over-expression of Socs1-3 and Cish. These results, as a whole, provide evidence for the first time that type II SOCS expression was effective in blocking GH-induced igf1 gene transcription via inhibition of $\mathrm{JAK}_{2} / \mathrm{STAT}_{5}$ signaling.

In summary, we have cloned the type II SOCS, including Socs1-3 and Cish, in grass carp and characterized their gene copy number and tissue expression profiles. In carp hepatocytes, GH treatment could induce transcript expression of these type II SOCS via $\mathrm{JAK}_{2} / \mathrm{STATs}_{\text {, MAPK, }}$ and/or PI3K/Akt cascades, and these effects were shown to occur before/during Igf1 down-regulation induced

\section{Working model in carp hepatocytes}

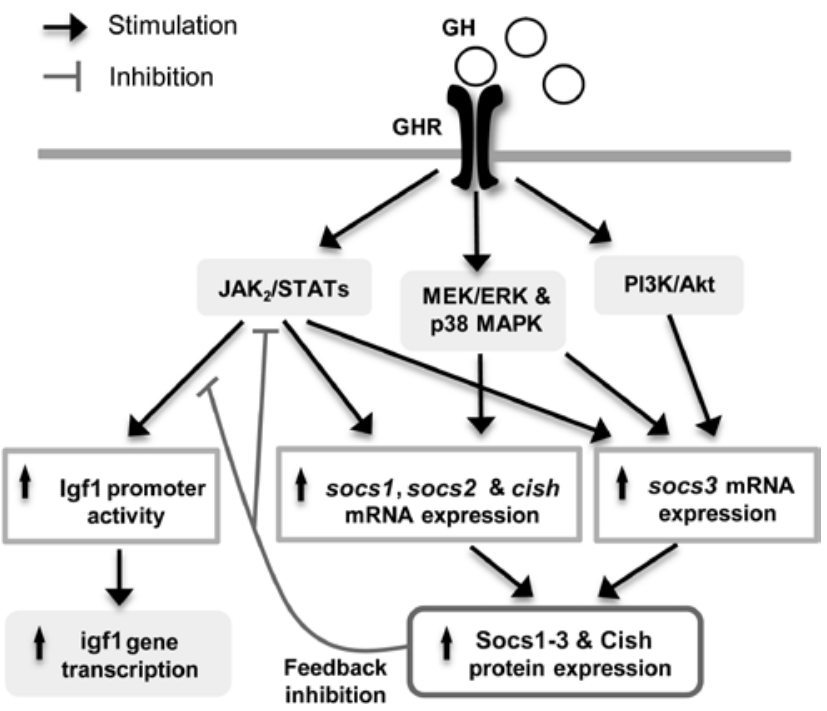

Figure 10

Working model for GH-induced type II SOCS expression and their effects on $\mathrm{JAK}_{2} / \mathrm{STAT}_{5}$ signaling and igf1 gene transcription in carp hepatocytes. In carp hepatocytes, GH stimulation can induce gene expression of type II SOCS including SOCS1-3 and CISH via JAK 2 / STATs, MAPK and/or PI3K/Akt cascades functionally coupled to GHR. The JAK $/$ /STATs pathway is also a major component in the post-receptor signal transduction for GH-induced Igf1 promoter activation and gene expression. Subsequent protein translation following the rises of type II SOCS mRNA induced by $\mathrm{GH}$ could elevate the levels of corresponding SOCS proteins in carp hepatocytes, which may serve as the intracellular feedback repressors to inhibit JAK $\mathrm{JTAT}_{5}$ pathway and lead to the down-regulation of Igf1 promoter activity and igf1 gene transcription occurred during the prolonged period of GHR activation. This intracellular feedback may constitute the intrinsic mechanisms acting at the hepatic level for signal termination of GH in the somatotropic axis in carp species.

by prolonged exposure to $\mathrm{GH}$. In $\mathrm{CHO}$ cells with GHR expression, GH could not only activate $\mathrm{JAK}_{2} / \mathrm{STAT}_{5}$ signaling but also up-regulate grass carp Igf1 promoter activity. These stimulatory actions, however, could be suppressed by over-expression of carp Socs1-3 and Cish. These findings, taken together, suggest that type II SOCS may serve as feedback repressors for GH activation of $\mathrm{JAK}_{2} / \mathrm{STAT}_{5}$ signaling and igf 1 gene transcription in the carp liver (Fig. 10). Probably, GHR activation could induce igf1 and type II SOCS gene expression via overlapping signal transduction pathways, and the subsequent rises in SOCS proteins might act as the negative feedback signals to inhibit GH-induced Igf1 expression at hepatic level. Whether type II SOCS can also contribute to the pulsatile pattern of Igf1 expression induced by GH (e.g., in rodents, Choi \& Waxman 2000) is still unclear; however, our studies do provide (i) the evidence for the presence of an intracellular feedback for signal termination of GH in the carp liver and (ii) a new insight into the possible cross talk

Published by Bioscientifica Ltd. 
between immune system and somatotropic axis in fish model. As GH resistance caused by bacterial/viral infection is known to compromise the overall productivity of fish farming, our findings may have potential application in developing new strategy targeting type II SOCS expression for growth promotion in commercial fish.

\section{Supplementary data}

This is linked to the online version of the paper at http://dx.doi.org/10.1530/ JOE-15-0423.

\section{Declaration of interest}

The authors declare that there is no conflict of interest that could be perceived as prejudicing the impartiality of the research reported.

\section{Funding}

The project was supported by GRF Grants (780312, 781113, and 17128215) and NSFC/RGC Joint Research Scheme (N_HKU732/12) from the Research Grant Council, Hong Kong (to AOLW).

\section{Author contribution statement}

$X \mathrm{~J}$ and $\mathrm{J} X$ were responsible for molecular cloning, gene copy number determination, tissue distribution, and transcript expression for grass carp type II SOCS; A M was in charge of hepatocyte preparation and GH-induced igf1 gene expression; $\mathrm{M} \mathrm{H}$ took care of LC/MS/MS for protein expression of type II SOCS and Western blot for signaling kinases; A O L W was the $\mathrm{PI}$ and grant holder, and worked with $\mathrm{X} J$ on manuscript preparation and revision.

\section{Acknowledgements}

Financial support from School of Biological Sciences (University of Hong Kong, Hong Kong) in the form of postgraduate studentship (to $\mathrm{X} \mathrm{J}, \mathrm{J} \mathrm{X}$, and $\mathrm{A}$ M) is also acknowledged. We also thank Peter $S$ Rotwein (Oregon Health and Science University, Portland, OR, USA) for sending us the $\mathrm{JAK}_{2} / \mathrm{STAT}_{5}$-responsive reporter and $\mathrm{STAT}_{5}$ expression vector for testing of the functionality of type II SOCS expression in $\mathrm{CHO}$ cells.

\section{References}

Adams TE, Hansen JA, Starr R, Nicola NA, Hilton DJ \& Billestrup N 1998 Growth hormone preferentially induces the rapid, transient expression of SOCS-3, a novel inhibitor of cytokine receptor signaling. Journal of Biological Chemistry 273 1285-1287. (doi:10.1074/jbc.273.3.1285)

Ahmed SF \& Farquharson C 2010 The effect of GH and IGF1 on linear growth and skeletal development and their modulation by SOCS proteins. Journal of Endocrinology 206 249-259. (doi:10.1677/ JOE-10-0045)

Birzniece V, Sata A \& Ho KK 2009 Growth hormone receptor modulators. Reviews in Endocrine and Metabolic Disorders 10 145-156. (doi:10.1007/s11154-008-9089-x)
Boisclair YR, Wang J, Shi J, Hurst KR \& Ooi GT 2000 Role of the suppressor of cytokine signaling-3 in mediating the inhibitory effects of interleukin- $1 \beta$ on the growth hormone-dependent transcription of the acid-labile subunit gene in liver cells. Journal of Biological Chemistry 275 3841-3847. (doi:10.1074/jbc.275.6.3841)

Brand S, Dambacher J, Beigel F, Zitzmann K, Heeg MHJ, Weiss TS, Prufer T, Olszak T, Steib CJ, Storr M, et al. 2007 IL-22-mediated liver cell regeneration is abrogated by SOCS-1/3 overexpression in vitro. American Journal of Physiology: Gastrointestinal and Liver Physiology 292 G1019-G1028. (doi:10.1152/ajpgi.00239.2006)

Cheng SM, Li JC, Lin SS, Lee DC, Liu L, Chen Z \& Lau AS 2009 HIV-1 transactivator protein induction of suppressor of cytokine signaling-2 contributes to dysregulation of IFN $\gamma$ signaling. Blood 113 5192-5201. (doi:10.1182/blood-2008-10-183525)

Choi HK \& Waxman DJ 2000 Pulsatility of growth hormone $(\mathrm{GH})$ signalling in liver cells: role of the JAK-STAT5b pathway in GH action. Growth Hormone \& IGF Research 10 (Supplement B) S1-S8. (doi:10.1016/S1096-6374(00)80002-7)

Croker BA, Kiu H \& Nicholson SE 2008 SOCS regulation of the JAK/STAT signalling pathway. Seminars in Cell \& Developmental Biology 19 414-422. (doi:10.1016/j.semcdb.2008.07.010)

Davey HW, Xie T, McLachlan MJ, Wilkins RJ, Waxman DJ \& Grattan DR 2001 STAT5b is required for GH-induced liver Igf-I gene expression. Endocrinology 142 3836-3841. (doi:10.1210/endo.142.9.8400)

Delgado-Ortega M, Melo S \& Meurens F 2011 Expression of SOCS1-7 and CIS mRNA in porcine tissues. Veterinary Immunology and Immunopathology 144 493-498. (doi:10.1016/j.vetimm.2011.08.002)

Favre H, Benhamou A, Finidori J, Kelly PA \& Edery M 1999 Dual effects of suppressor of cytokine signaling (SOCS-2) on growth hormone signal transduction. FEBS Letters 453 63-66. (doi:10.1016/S00145793(99)00681-X)

Greenhalgh CJ \& Alexander WS 2004 Suppressors of cytokine signalling and regulation of growth hormone action. Growth Hormone \& IGF Research 14 200-206. (doi:10.1016/j.ghir.2003.12.011)

Greenhalgh CJ, Bertolino P, Asa SL, Metcalf D, Corbin JE, Adams TE, Davey HW, Nicola NA, Hilton DJ \& Alexander WS 2002a Growth enhancement in suppressor of cytokine signaling 2 (SOCS-2)-deficient mice is dependent on signal transducer and activator of transcription 5b (STAT5b). Molecular Endocrinology 16 1394-1406.

Greenhalgh CJ, Metcalf D, Thaus AL, Corbin JE, Uren R, Morgan PO, Fabri LJ, Zhang JG, Martin HM, Willson TA, et al. 2002b Biological evidence that SOCS-2 can act either as an enhancer or suppressor of growth hormone signaling. Journal of Biological Chemistry $\mathbf{2 7 7}$ 40181-40184. (doi:10.1074/jbc.C200450200)

Greenhalgh CJ, Rico-Bautista E, Lorentzon M, Thaus AL, Morgan PO, Willson TA, Zervoudakis P, Metcalf D, Street I, Nicola NA, et al. 2005 SOCS2 negatively regulates growth hormone action in vitro and in vivo. Journal of Clinical Investigation 115 397-406. (doi:10.1172/ JCI200522710)

Hansen JA, Lindberg K, Hilton DJ, Nielsen JH \& Billestrup N 1999 Mechanism of inhibition of growth hormone receptor signaling by suppressor of cytokine signaling proteins. Molecular Endocrinology $\mathbf{1 3}$ 1832-1843. (doi:10.1210/mend.13.11.0368)

Hebenstreit D, Luft P, Schmiedlechner A, Regl G, Frischauf AM, Aberger F, Duschl A \& Horejs-Hoeck J 2003 IL-4 and IL-13 induce SOCS-1 gene expression in A549 cells by three functional STAT6-binding motifs located upstream of the transcription initiation site. Journal of Immunology 171 5901-5907. (doi:10.4049/jimmunol.171.11.5901)

Hilton DJ 1999 Negative regulators of cytokine signal transduction. Cellular and Molecular Life Sciences 55 1568-1577. (doi:10.1007/ s000180050396)

Jiang Q \& Wong AO 2013 Signal transduction mechanisms for autocrine/ paracrine regulation of somatolactin $\alpha$ secretion and synthesis in carp pituitary cells by somatolactin $\alpha$ and $\beta$. American Journal of Physiology: Endocrinology and Metabolism 304 E176-E186. (doi:10.1152/ ajpendo.00455.2012) 
Jin HJ, Xiang LX \& Shao JZ 2007 Identification and characterization of suppressor of cytokine signaling 1 (SOCS-1) homologues in teleost fish. Immunogenetics 59 673-686. (doi:10.1007/s00251-007-0232-8)

Jin H-J, Shao J-Z, Xiang L-X, Wang H \& Sun L-L 2008 Global identification and comparative analysis of SOCS genes in fish: Insights into the molecular evolution of SOCS family. Molecular Immunology 45 1258-1268. (doi:10.1016/j.molimm.2007.09.015)

Kassahn KS, Dang VT, Wilkins SJ, Perkins AC \& Ragan MA 2009 Evolution of gene function and regulatory control after wholegenome duplication: comparative analysis in vertebrates. Genome Research 19 1404-1418. (doi:10.1101/gr.086827.108)

Liang Y, Xu WD, Peng H, Pan HF \& Ye DQ 2014 SOCS signaling in autoimmune diseases: molecular mechanisms and therapeutic implications. European Journal of Immunology 44 1265-1275. (doi:10.1002/eji.201344369)

Lin C, Jiang X, Hu G, Ko WK \& Wong AO 2015 Grass carp prolactin: molecular cloning, tissue expression, intrapituitary autoregulation by prolactin and paracrine regulation by growth hormone and luteinizing hormone. Molecular and Cellular Endocrinology 399 267-283. (doi:10.1016/j.mce.2014.10.010)

Liu BA, Jablonowski K, Raina M, Arce M, Pawson T \& Nash PD 2006 The human and mouse complement of SH2 domain proteins - establishing the boundaries of phosphotyrosine signaling. Molecular Cell 22 851-868. (doi:10.1016/j.molcel.2006.06.001)

Machida K \& Mayer BJ 2005 The SH2 domain: versatile signaling module and pharmaceutical target. Biochimica et Biophysica Acta 1747 1-25. (doi:10.1016/j.bbapap.2004.10.005)

Maehr T, Vecino JL, Wadsworth S, Wang T \& Secombes CJ 2014 Four CISH paralogues are present in rainbow trout Oncorhynchus mykiss: differential expression and modulation during immune responses and development. Molecular Immunology 62 186-198. (doi:10.1016/ j.molimm.2014.06.021)

Metcalf D, Greenhalgh CJ, Viney E, Willson TA, Starr R, Nicola NA, Hilton DJ \& Alexander WS 2000 Gigantism in mice lacking suppressor of cytokine signalling-2. Nature $\mathbf{4 0 5}$ 1069-1073. (doi:10.1038/35016611)

Miquet JG, Munoz MC, Giani JF, Gonzalez L, Dominici FP, Bartke A, Turyn D \& Sotelo AI 2010 Ames dwarf (Prop1(df)/Prop1(df)) mice display increased sensitivity of the major GH-signaling pathways in liver and skeletal muscle. Growth Hormone \& IGF Research 20 118-126. (doi:10.1016/j.ghir.2009.11.003)

Miyoshi H, Fujie H, Shintani Y, Tsutsumi T, Shinzawa S, Makuuchi M, Kokudo N, Matsuura Y, Suzuki T, Miyamura T, et al. 2005 Hepatitis $\mathrm{C}$ virus core protein exerts an inhibitory effect on suppressor. of cytokine signaling (SOCS)-1 gene expression. Journal of Hepatology $\mathbf{4 3}$ 757-763. (doi:10.1016/j.jhep.2005.03.028)

Moghadam HK, Ferguson MM, Rexroad CE, Coulibaly I \& Danzmann RG 2007 Genomic organization of the IGF1, IGF2, MYF5, MYF6 and GRF/ PACAP genes across Salmoninae genera. Animal Genetics 38 527-532. (doi:10.1111/j.1365-2052.2007.01645.x)

Philip AM, Vijayan MM, Boudinot P 2015 Stress-immune-growth interactions: cortisol modules suppressor of cytokine signaling and JAK/STAT pathway in rainbow trout liver. PLOS ONE 10 e0129299. (doi:10.1371/journal.pone.0129299)

Piessevaux J, De Ceuninck L, Catteeuw D, Peelman F \& Tavernier J 2008 a Elongin $\mathrm{B} / \mathrm{C}$ recruitment regulates substrate binding by CIS. Journal of Biological Chemistry 283 21334-21346. (doi:10.1074/jbc.M803742200)

Piessevaux J, Lavens D, Peelman F \& Tavernier J 2008b The many faces of the SOCS box. Cytokine \& Growth Factor Reviews 19 371-381. (doi:10.1016/j.cytogfr.2008.08.006)

Racanelli V \& Rehermann B 2006 The liver as an immunological organ. Hepatology 43 S54-S62. (doi:10.1002/hep.21060)

Reindl KM, Kittilson JD, Bergan HE \& Sheridan MA 2011 Growth hormone-stimulated insulin-like growth factor-1 expression in rainbow trout (Oncorhynchus mykiss) hepatocytes is mediated by ERK, PI3K-AKT, and JAK-STAT. American Journal of Physiology: Regulatory, http://joe.endocrinology-journals.org

DOI: $10.1530 / J O E-15-0423$
(C) 2016 Society for Endocrinology Printed in Great Britain
Integrative and Comparative Physiology 301 R236-R243. (doi:10.1152/ ajpregu.00414.2010)

Sadowski CL, Wheeler TT, Wang LH \& Sadowski HB 2001 GH regulation of IGF-I and suppressor of cytokine signaling gene expression in C2C12 skeletal muscle cells. Endocrinology 142 3890-3900. (doi:10.1210/endo.142.9.8365)

Shepherd BS, Rees CB, Binkowski FP \& Goetz FW 2012 Characterization and evaluation of sex-specific expression of suppressors of cytokine signaling (SOCS)-1 and -3 in juvenile yellow perch (Perca flavescens) treated with lipopolysaccharide. Fish and Shellfish Immunology $\mathbf{3 3}$ 468-484. (doi:10.1016/j.fsi.2012.05.026)

Skjesol A, Liebe T, Iliev DB, Thomassen EI, Tollersrud LG, Sobhkhex M, Joensen L, Secombes CJ \& Jorgensen JB 2014 Functional conservation of suppressor of cytokine signaling proteins between teleosts and mammals: Atlantic salmon SOCS1 binds to JAK/STAT family members and suppresses type I and II IFN signaling. Developmental and Comparative Immunology 45 177-189. (doi:10.1016/j.dci.2014.02.009)

Strebovsky J, Walker P \& Dalpke AH 2012 Suppressor of cytokine signaling proteins as regulators of innate immune signaling. Frontiers in Bioscience (Landmark) 17 1627-1639. (doi:10.2741/4008)

Studzinski ALM, Almeida DV, Lanes CFC, Figueiredo MD \& Marins LF 2009 SOCS1 and SOCS3 are the main negative modulators of the somatotrophic axis in liver of homozygous GH-transgenic zebrafish (Danio rerio). General and Comparative Endocrinology 161 67-72. (doi:10.1016/j.ygcen.2008.10.008)

Sun C, He M, Ko WK \& Wong AO 2014 Mechanisms for luteinizing hormone induction of growth hormone gene transcription in fish model: crosstalk of the cAMP/PKA pathway with MAPK-and PI3K- dependent cascades. Molecular and Cellular Endocrinology 382 835-850. (doi:10.1016/j.mce.2013.10.017)

Tamiya T, Kashiwagi I, Takahashi R, Yasukawa H \& Yoshimura A 2011 Suppressors of cytokine signaling (SOCS) proteins and JAK/ STAT pathways regulation of T-Cell inflammation by SOCS1 and SOCS3. Arteriosclerosis, Thrombosis, and Vascular Biology 31 980-985. (doi:10.1161/ATVBAHA.110.207464)

Tollet-Egnell P, Flores-Morales A, Stavreus-Evers A, Sahlin L \& Norstedt G 1999 Growth hormone regulation of SOCS-2, SOCS-3, and CIS messenger ribonucleic acid expression in the rat. Endocrinology 140 3693-3704. (doi:10.1210/endo.140.8.6878)

Vesterlund M, Zadjali F, Persson T, Nielsen ML, Kessler BM, Norstedt G \& Flores-Morales A 2011 The SOCS2 ubiquitin ligase complex regulates growth hormone receptor levels. PLOS ONE 6 e25358. (doi:10.1371/ journal.pone.0025358)

Vijayakumar A, Novosyadlyy R, Wu YJ, Yakar S \& LeRoith D 2010 Biological effects of growth hormone on carbohydrate and lipid metabolism. Growth Hormone \& IGF Research 20 1-7. (doi:10.1016/j. ghir.2009.09.002)

Vong QP, Chan KM \& Cheng CH 2003 Quantification of common carp (Cyprinus carpio) IGF-I and IGF-II mRNA by real-time PCR: differential regulation of expression by GH. Journal of Endocrinology 178 513-521. (doi:10.1677/joe.0.1780513)

Wang T \& Secombes CJ 2008 Rainbow trout suppressor of cytokine signalling (SOCS)-1, 2 and 3: molecular identification, expression and modulation. Molecular Immunology 45 1449-1457. (doi:10.1016/j. molimm.2007.08.016)

Wang T, Gao Q, Nie P \& Secombes CJ 2010 Identification of suppressor of cytokine signalling (SOCS) 6, 7, 9 and CISH in rainbow trout Oncorhynchus mykiss and analysis of their expression in relation to other known trout SOCS. Fish and Shellfish Immunology 29 656-667. (doi:10.1016/j.fsi.2010.06.015)

Wang T, Gorgoglione B, Maehr T, Holland JW, Vecino JL, Wadsworth S \& Secombes CJ 2011 Fish suppressors of cytokine signaling (SOCS): gene discovery, modulation of expression and function. Journal of Signal Transduction 2011 905813. (doi:10.1155/2011/905813)

Wong MK, Sze KH, Chen T, Cho CK, Law HC, Chu IK \& Wong AO 2013 Goldfish spexin: solution structure and novel function as 
a satiety factor in feeding control. American Journal of Physiology: Endocrinology and Metabolism 305 E348-E366. (doi:10.1152/ ajpendo.00141.2013)

Yao J, Mu W, Liu S, Zhang J, Wen H \& Liu Z 2015 Identification, phylogeny and expression analysis of suppressors of cytokine signaling in channel catfish. Molecular Immunology 64 276-284. (doi:10.1016/j.molimm.2014.12.003)
Yoshimura A, Naka T \& Kubo M 2007 SOCS proteins, cytokine signalling and immune regulation. Nature Reviews Immunology 7 454-465. (doi:10.1038/nri2093)

Zhang M, Xiao ZZ \& Sun L 2011 Suppressor of cytokine signaling 3 inhibits head kidney macrophage activation and cytokine expression in Scophthalmus maximus. Developmental and Comparative Immunology 35 174-181. (doi:10.1016/j.dci.2010.09.006)

Received in final form 8 February 2016

Accepted 14 March 2016

Accepted Preprint published online 14 March 2016
Published by Bioscientifica Ltd. 